\title{
51. SEISMIC STRATIGRAPHY AND HISTORY OF DEEP CIRCULATION AND SEDIMENT DRIFT DEVELOPMENT IN BAFFIN BAY AND THE LABRADOR SEA ${ }^{1}$
}

\author{
M. A. Arthur, ${ }^{2}$ S. P. Srivastava, ${ }^{3}$ M. Kaminski, ${ }^{4}$ R. Jarrard, ${ }^{5}$ and J. Osler ${ }^{4}$
}

\begin{abstract}
Drilling results and seismic-reflection records at and across Ocean Drilling Program (ODP) Sites 645 (western Baffin Bay), 646, and 647 (Labrador Sea) provide important constraints on the history of deep-water circulation and sedimentation in response to Cenozoic climatic change, as well as the tectonic evolution of the region. Sites 646 and 647 were drilled on the flanks of two sediment drift deposits-the Eirik Ridge and Gloria Drift, respectively. Age control at Site 645 was poor because of the restricted biotas there, but the drill site provides a continuous sequence from the lower Miocene to the present. Sediment at Site 646 was deposited at high rates, providing a high resolution record of the last 8.5 $\mathrm{Ma}$. At Site 647 sedimentation was variable and discontinuous, but a complete upper-lower Eocene through lower Oligocene sequence was recovered, whereas the upper Oligocene to Holocene sequence was interrupted by several hiatuses.

The drift sequence at Site 646 was constructed after the middle to early Pliocene (ca. $4.5 \mathrm{Ma}$ ). Before that time, evidence exists for variable bottom-current activity, with events at about $7.5 \mathrm{Ma}$ (a change in water-mass characteristics and decreasing velocities) and $5.6 \mathrm{Ma}$ (an increase in current velocity preceding the major 4.5-Ma event; R2 regional reflector). The 7.5-Ma event produced a major regional reflector (R3/R4), which was originally thought to be Eocene/ Oligocene in age. A major water-mass change also occurred at the onset of ice-rafting at about $2.5 \mathrm{Ma}$ in the late Pliocene. In seismic records no evidence exists of drift building before the early Pliocene, but a probable late-middle Miocene erosional event occurred on the south flank of Eirik Ridge and along the West Greenland margin. Sediment supply from the Imarssuak mid-ocean canyon (IMOC) increased concurrently with the advent of drift construction.

Gloria Drift also was built largely after the late Miocene. A major increase in sediment supply occurred in the early Pliocene, following a major hiatus (5.6 to $2.5 \mathrm{Ma}$; equivalent to the youngest possible age for the R2 reflector underlying Gloria Drift), and most seismic records exhibit sediment waves above this horizon. This increased sediment supply is the result of hemipelagic deposition from encroaching deposits of the North Atlantic mid-ocean canyon, as well as to supply of ice-rafted detritus in the late Pliocene. A hiatus encompasses the interval from approximately 17.5 to $8.2 \mathrm{Ma}$, and the interval between the two major hiatuses is extremely condensed. A deeper reflector (R3) corresponds to a change from calcareous (below) to opal-rich hemipelagic strata in the lower Oligocene, not to a regional unconformity reflecting increased bottom-water activity, as previously thought. However, some evidence exists to support a latest Eocene-earliest Oligocene increase in bottom-current activity on Gloria Drift.

In Baffin Bay, there is evidence for bottom-water activity from textural studies of cores and from apparent drift features exhibited in multichannel lines along the western margin. Probable contour-currents have been active since at least the late middle Miocene, with episodes of decreasing intensity that apparently occurred in the late Miocene and Quaternary. The record from Site 645 and in seismic lines may indicate that formation of bottom water occurred in the late Neogene in Baffin Bay in conjunction with climatic deterioration, but Baffin Bay was not an important source of deepwater masses to the Labrador Sea after the late Pliocene.

Not surprisingly, many of the Labrador Sea deep-circulation events correspond closely to major North Atlantic events and to important global climatic and paleoceanographic events, but a major drift-building episode may have occurred later in the Labrador Sea than it did in either the eastern North Atlantic or the western North Atlantic.
\end{abstract}

\section{INTRODUCTION}

The links between eustacy, climate, and deep-water circulation have been a topic of research and debate for some time (e.g., Moore et al., 1978; Miller et al., 1989; Keller and Barron, 1983). Much of this work has focused on the North Atlantic Basin (e.g., Miller and Tucholke, 1983; Mountain and Tucholke, 1985; Kidd and Hill, 1986a) because a major deep-water mass, North Atlantic Deep Water (NADW), presently forms in the Norwegian-Greenland Sea and spills into the deep North Atlantic over the Greenland-Iceland-Faroes Ridge (Worthington and Volkman, 1965). This deep-current system today actively sculpts

\footnotetext{
${ }^{1}$ Srivastava, S. P., Arthur, M., Clement, B., 1989. Proc. ODP, Sci. Results, 105: College Station, TX (Ocean Drilling Program).

2 Graduate School of Oceanography, University of Rhode Island, Narragansett, RI 02882 .

3 Atlantic Geoscience Centre, Geological Survey of Canada, Bedford Institute of Oceanography, Box 1006, Dartmouth, Nova Scotia B2Y 4A2, Canada.

${ }^{4}$ Centre for Marine Geology, Dalhousie University, Halifax, Nova Scotia B3H 3J5, Canada.

5 Lamont-Doherty Geological Observatory, Columbia University, Palisades, NY 10964.
}

much of the North American continental rise as a major western-boundary contour current (Fig. 1; see McCave and Tucholke, 1986, for review) and probably was active over much of the late Cenozoic as well (e.g., Mountain and Tucholke, 1985). Episodicity in the intensity of the deep circulation has been suggested on the basis of widespread, intrabasinal reflectors (see Tucholke and Mountain, 1986, for review) that apparently reflect erosion by bottom currents and because of the construction of current-influenced sedimentary bodies termed "sediment drifts" along much of the continental margin (Fig. 1; McCave and Tucholke, 1986).

One of the major objectives of Leg 105 drilling was to examine the record of construction of two important sediment drifts (Stow and Holbrook, 1984; McCave and Tucholke, 1986) in the Labrador Sea. Site 646 was drilled on the northwestern flank of Eirik Ridge off the southwest margin of Greenland, and Site 647 was drilled on the southwestern flank of Gloria Drift in the southwestern Labrador Sea (Fig. 1). Both sites contribute important data for age calibration of a fairly extensive network of single and multichannel seismic-reflection records, and studies of the core material allow us to draw inferences about the timing of climatic, circulation, and sedimentation events. In addition, 


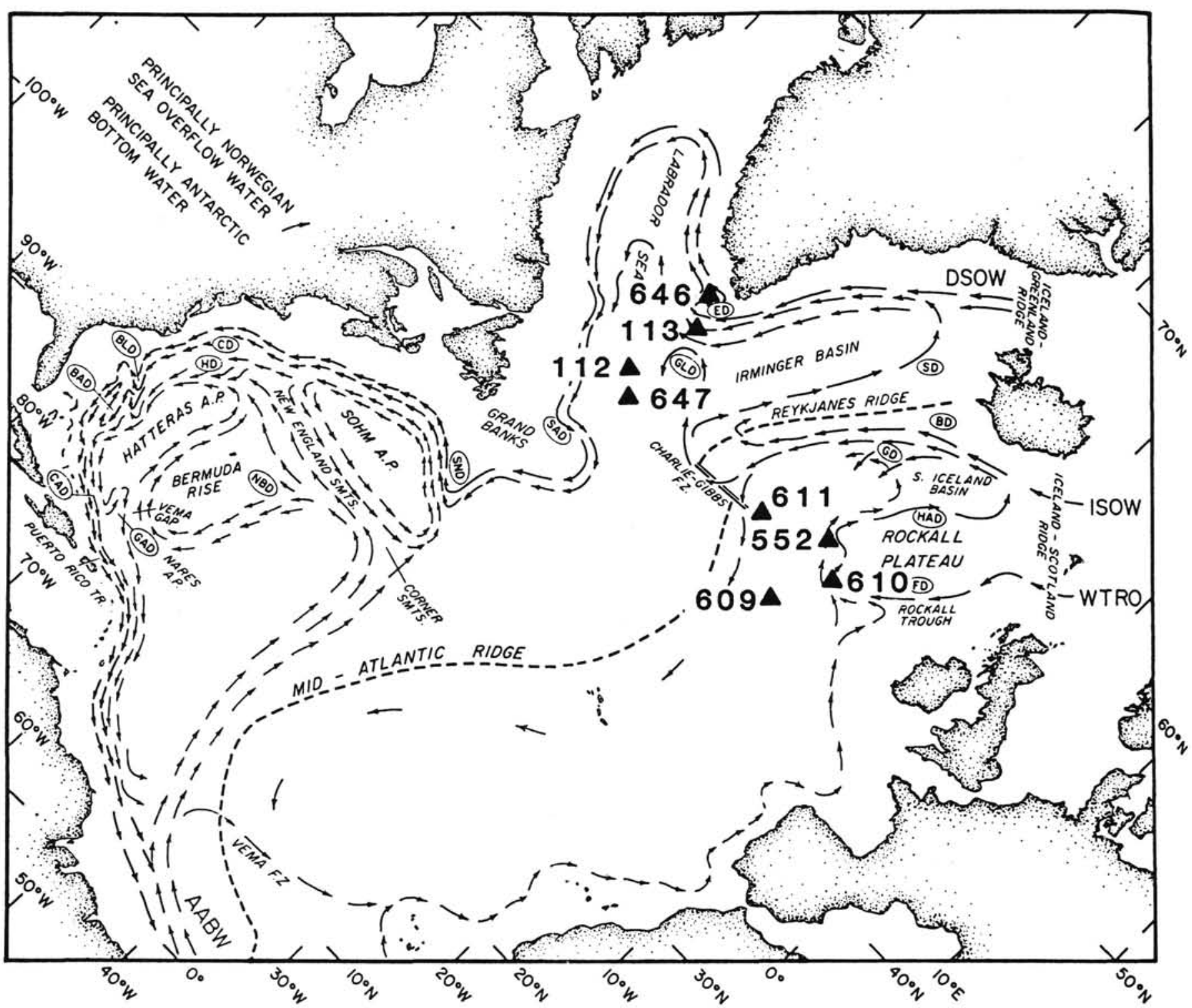

Figure 1. Mercator projection of the North Atlantic Ocean Basin showing present patterns of deep-water circulation and major sediment drift deposits (after McCave and Tucholke, 1986) with locations of DSDP-ODP sites referred to in text. "ED" and "GLD" refer to Eirik Drift and Gloria Drift deposits, respectively, in the Labrador Sea. Also shown are major sources of deep water (AABW-Antarctic Bottom Water; DSOW-Denmark Straits Overflow Water; ISOW-Ireland-Scotland Overflow Water; WTRO-Wyville-Thomson Ridge Overflow Water). Sites in the Labrador Sea lie within the influence of NSOW (i.e., NADW) sources (NSOW-Norwegian Sea Overflow Water, NADW-North Atlantic Deep Water), whereas the eastern North Atlantic sites are characterized by combined AABW-NSOW sources.

we were able to drill Site 645 in southern Baffin Bay, off the Baffin Island margin (Fig. 2), where we recovered a record of high-latitude early Miocene to Holocene sedimentation and climate indicators. Biostratigraphic resolution is not as good at Site 645 as it is at Sites 646 and 647 , but we were able to assign reasonable ages to events in the sequence. Unexpectedly, the Site 645 record revealed evidence of strong contour-current activity on the western margin of Baffin Bay over much of the Miocene and Pliocene, which is also manifested by features interpreted as sediment drifts that appear in several multichannel seismic records. The purpose of this chapter is to summarize and put into perspective the major events and trends in deep-current activity in Baffin Bay and the Labrador Sea on the basis of seismic stratigraphy and drilling results and to compare our interpretation of the record to events that occurred in the rest of the North Atlantic during the late Cenozoic.
Our interpretation of the seismic-reflection data at the ODP sites is based largely on the analyses of reflector depths and ages that were done for the initial report (Srivastava, Arthur, et al., 1987), with modification and extension away from the sites as outlined here.

\section{SEISMIC SEQUENCES AT LEG 105 SITES}

\section{Site 646: Neogene Record on Eirik Ridge}

Drilling at Site 646 and an extensive regional seismic network (Fig. 3) of single and multichannel records provide us with a basis for examining the seismic stratigraphy and bottom-current, erosional, sediment-drift development history of the northern Labrador Sea. In particular, we can examine the history of sedimentation on Eirik Ridge. Eirik Ridge (Fig. 4) is a constructional sedimentary feature (Johnson and Schneider, 1969), lo- 


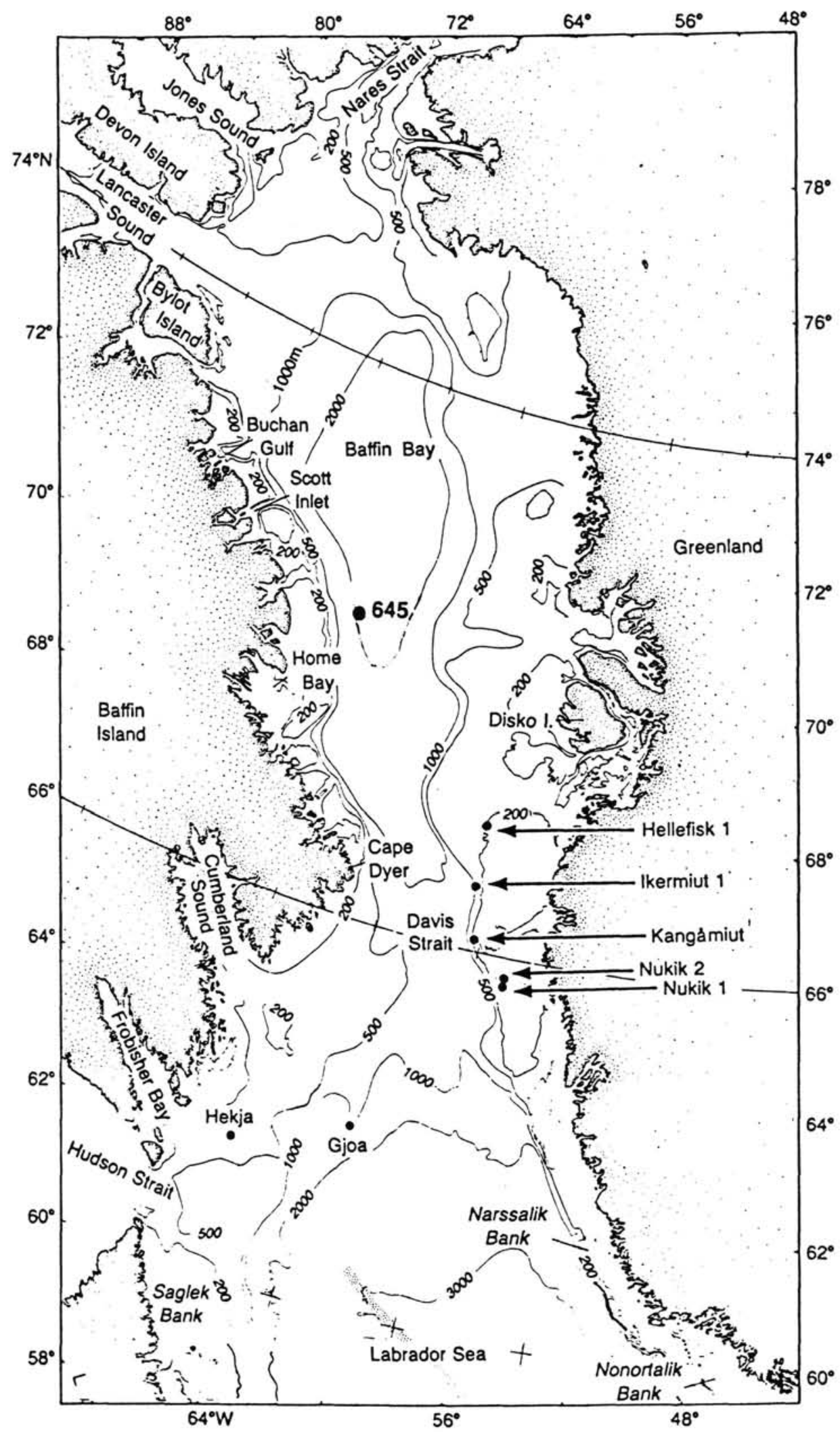

Figure 2. Index map showing location of Site 645 in southern Baffin Bay and the bathymetry of Davis Strait, the passage between Baffin Bay and the Labrador Sea. 


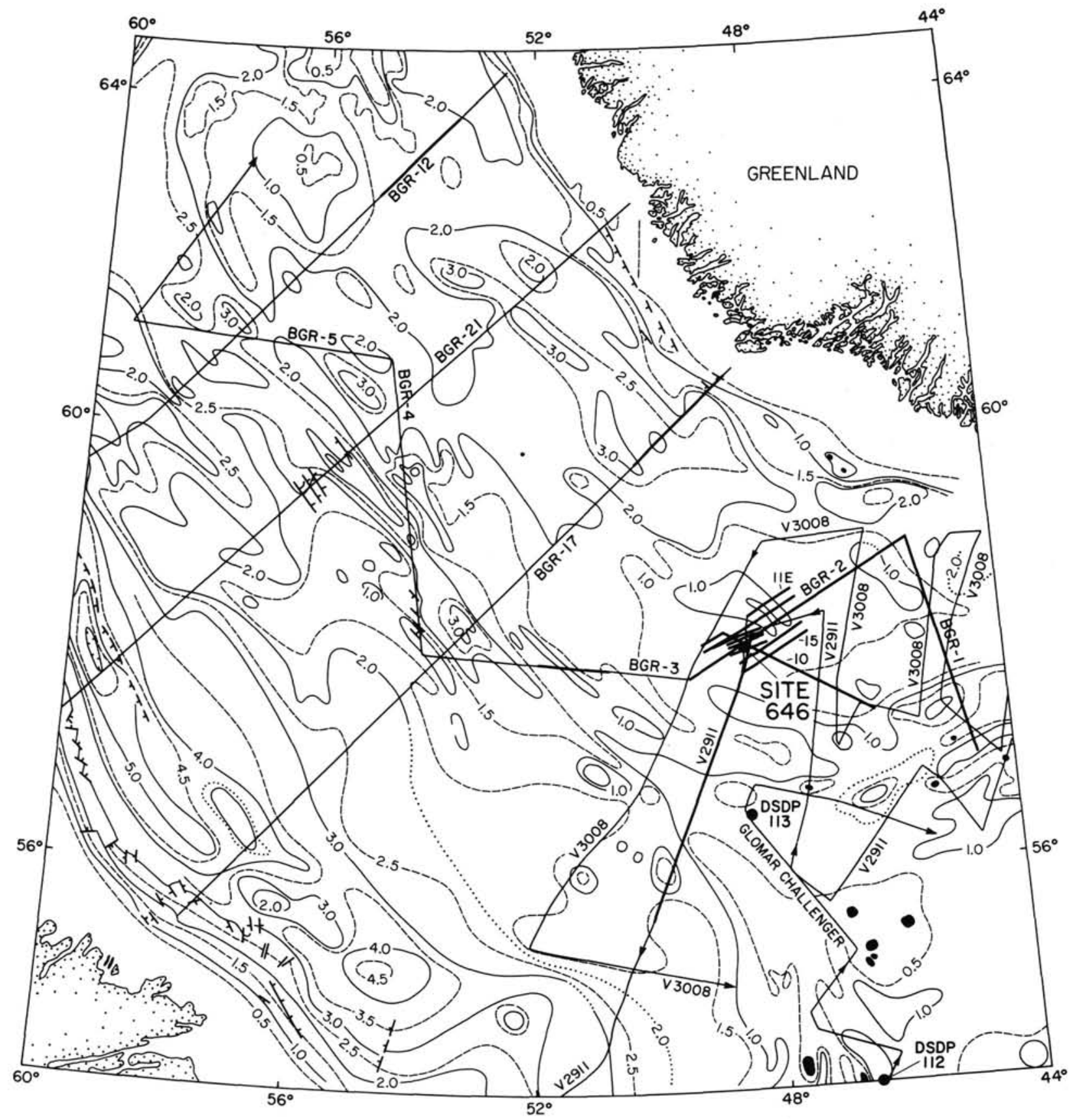

Figure 3. Locations of seismic-reflection lines off southwest Greenland in the northern Labrador Sea. Note location of Site 646 and net of seismic lines in vicinity of Eirik Ridge. Contours are total sediment thickness in two-way traveltime in seconds.

cated where it was influenced by the interaction of the roughly southwestward-flowing western boundary undercurrent (Jones et al., 1970), and it has a topography inherited from the basement. A fairly steep southeast-facing slope exists between the younger crust of the extinct spreading center east of the Leif Fracture Zone, which now is deeply subsided, and the older, more elevated crust on the southwest Greenland margin, which is probably transitional between oceanic and continental crust and/or is partly a constructional volcanic edifice. Since Site 646 is in the pathway of overflow from the Norwegian-Greenland Sea, studies of litho- and biofacies patterns contribute to our understanding of North Atlantic paleoceanography. Here, we first describe the age, lithology, and characteristics of the seismic stratigraphic units observed near Site 646 (Figs. 3A and 4) and then outline their pattern over the Eirik Ridge region. We are able to carry our seismic well ties to the Eirik Ridge through correlations between Hudson line 14, which crosses Site 646 (Fig. 5) and intersects the multichannel line BGR-2 roughly 16 $\mathrm{km}$ to the south (Fig. 3), through BGR-2 (Fig. 6) and to a second multichannel line, BGR-1, that runs northwest-southeast, perpendicular to the axis of Eirik Ridge. The BGR-1 line (Fig. 7) and, to some extent, the Hudson line 10 (Fig. 8) illustrate correlations and continuity of reflection characteristics and major seismic units of Site 646 across Eirik Ridge and to the south in the IMOC region of flat seafloor topography.

In addition to four major seismic sequences, we identified reflectors within each unit. These are correlated with geophysical logs and physical-property measurements performed on cores 


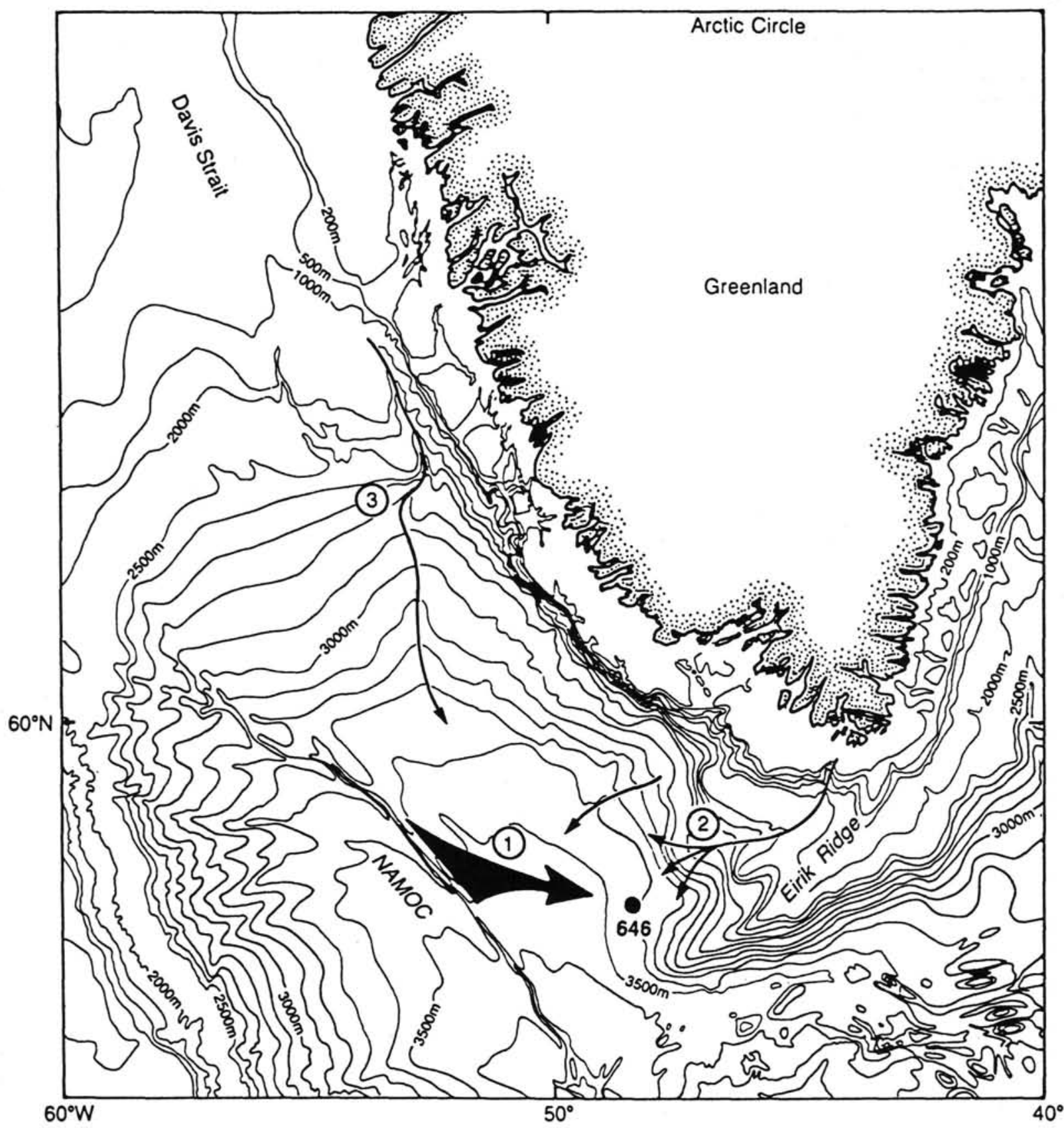

Figure 4. Regional bathymetry of the northern Labrador Sea showing the location of Site 646 relative to the topographic expression of the main part of Eirik Ridge. Arrows indicate inferred sediment sources to the vicinity of Site 646, including overspill from the Northeast Atlantic Mid-Ocean Channel (NAMOC).

recovered at this site (Fig. 9). For calculations of the depth to each reflector, we used the sonic velocities obtained from Srivastava, Arthur, et al. (1987). There is good agreement between average velocities obtained from the sonobuoy measurements in this region with those obtained from the sonic log. Although seismic records exhibit high-amplitude reflectors (inferred highimpedance contrasts), major lithologic differences across various seismic boundaries were not observed, nor do sonic logs exhibit major steps in velocity. Hence, some of the differences in the acoustic impedance must arise from both density and porosity variations (Fig. 9).

\section{Synthetic Seismogram for Site 646}

Reflectivity sequence is a function of the impedance contrast between adjacent sediment or rock layers. The magnitude of a given contrast determines its amplitude in the reflectivity sequence. Impedance in an interval is the product of the velocity and density within that interval. These values of velocity and density are obtained either from laboratory measurements of cores or by inversion of different physical-property logs run downhole. At Site 646, these two data types are complementary because $49 \%$ of the laboratory measurements were performed 


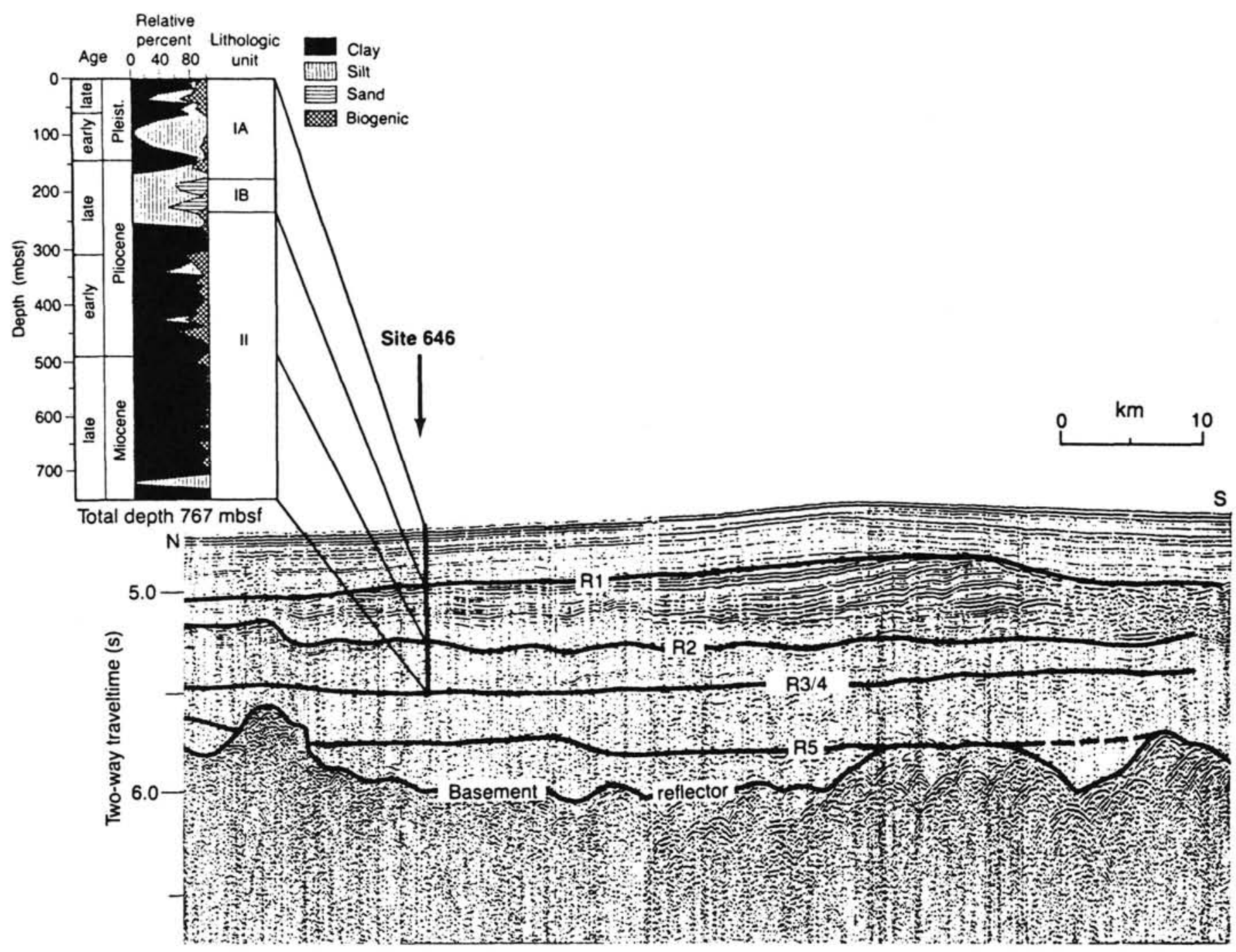

Figure 5. Segment of Hudson single-channel reflection line 14 running northwest-southeast across Site 646 in the northern Labrador Sea showing major reflection sequences, reflectors and correlation to the lithologic sequence at Site 646.

on cores from the upper 206 mbsf because sample recovery deeper in the hole was poor, whereas geophysical logs are of better quality and have a higher sampling frequency in the open hole (below $206 \mathrm{mbsf}$ ) than through the pipe (above $206 \mathrm{mbsf}$ ).

To produce a continuous velocity profile through the entire drilled sequence, Jarrard et al. (this volume) merged laboratory and logged data. Below 206 mbsf, logged velocities are used, as these are more continuous and representative (Fig. 9) than laboratory data, which are widely spaced and performed on small samples. Further, logged velocities are measured in situ, while laboratory measurements are complicated by having to apply a rebound correction. Above $206 \mathrm{mbsf}$, no log velocities are available, thus a pseudovelocity log was produced with velocities calculated using porosity and density measurements and Gassman's theoretical relationship (1951). These are used in preference to measured velocities because porosity and density measurements are more abundant and reliable.

To reconcile calculated velocity with log velocities between 206 and 340 mbsf, and to avoid an artificial velocity jump at 206 mbsf where the calculated and logged velocities are joined, Jarrard et al. (this volume) scale the data by a linear ramp running from 1.00 at 0 mbsf to 1.05 at 206 mbsf. Although this method is theoretically unsatisfactory, it does maintain the character of the velocity fluctuations, which are of prime importance.
A density log can be computed by a number of methods. Jarrard et al. (this volume) chose to compute a pseudodensity log using calculated values of grain density and porosity logs. In comparison with the pycnometer data, the pseudodensity logs exhibit less variance. This is not solely due to measurement and rebound errors in the pycnometer data, rather the logging tool averages data over a $1-\mathrm{m}$ interval in contrast to the discrete measurements by the pycnometer.

The porosity log itself was computed by inversion of a resistivity log. This inversion introduces uncertainties because the empirical relationship between resistivity and porosity contains two numerical constants dependent on lithology and the parameter $R w$, the resistivity of the formation water, which is sensitive to salinity and temperature. Salinity and temperature are both adversely affected by pumping seawater downhole during drilling. The grain density log is calculated using well-known grain densities of component minerals and percentages of these minerals from the inversion of the bound water log, the potassium $\log$, and the uranium/thorium ratio.

The final merged logs of density and velocity are considered very good in the intervals from 0 to $100 \mathrm{mbsf}$ and 206 to 737 mbsf, but less reliable in the interval from 100 to 206 mbsf, where data are sparsest and velocities most uncertain. The poor $\log$ quality in this interval creates a strong reflector in the syn- 


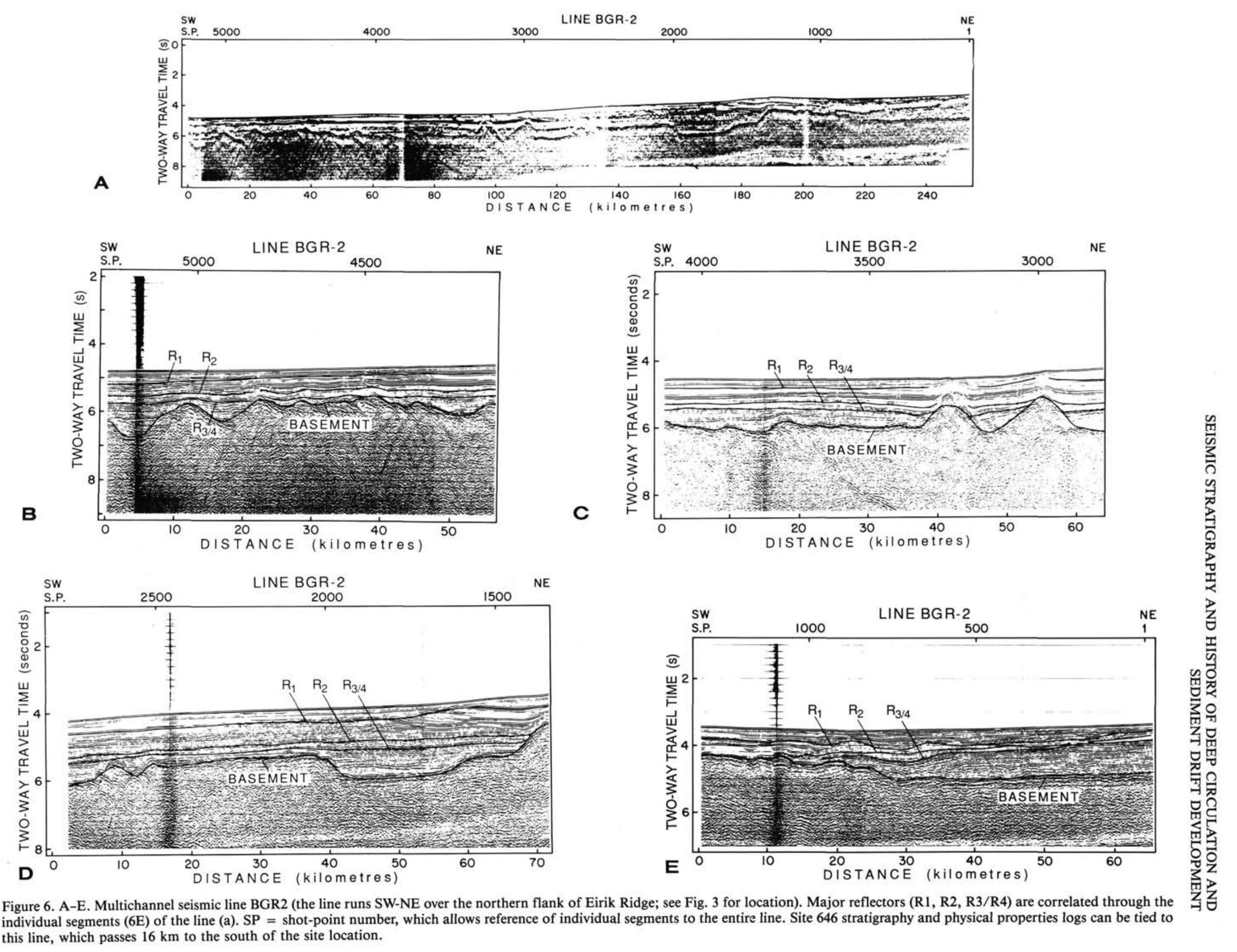



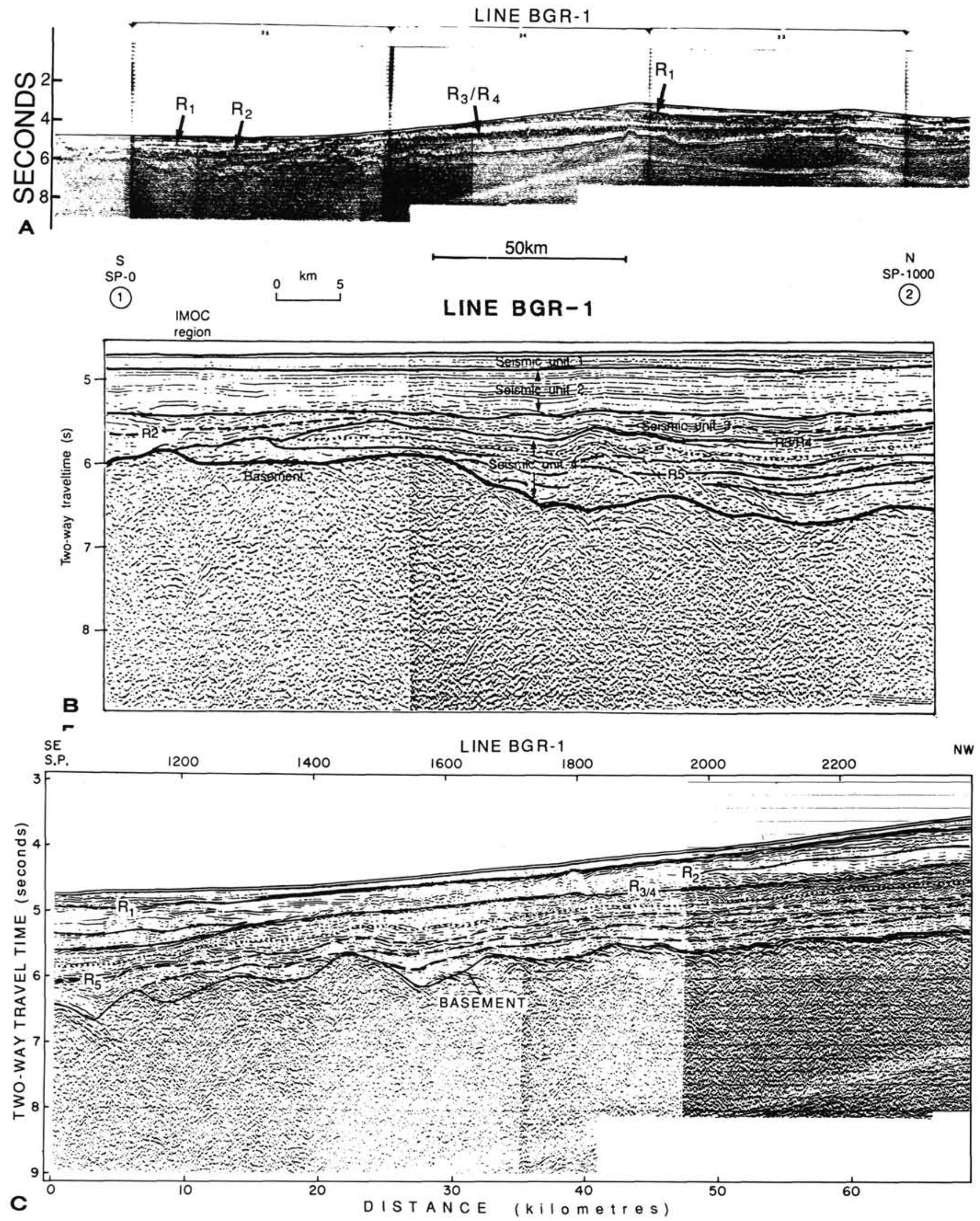

Figure 7. A. Complete multichannel seismic line BGR-1 that crosses Eirik Drift (see Fig. 3 for location) and ties to the eastern end of BGR-2 with major reflectors (R1, R2, R3/R4) shown. B-E. Segments of BGR1 showing seismic-reflection characteristics of sequences. The segments run from southeast to northwest (B-E). 

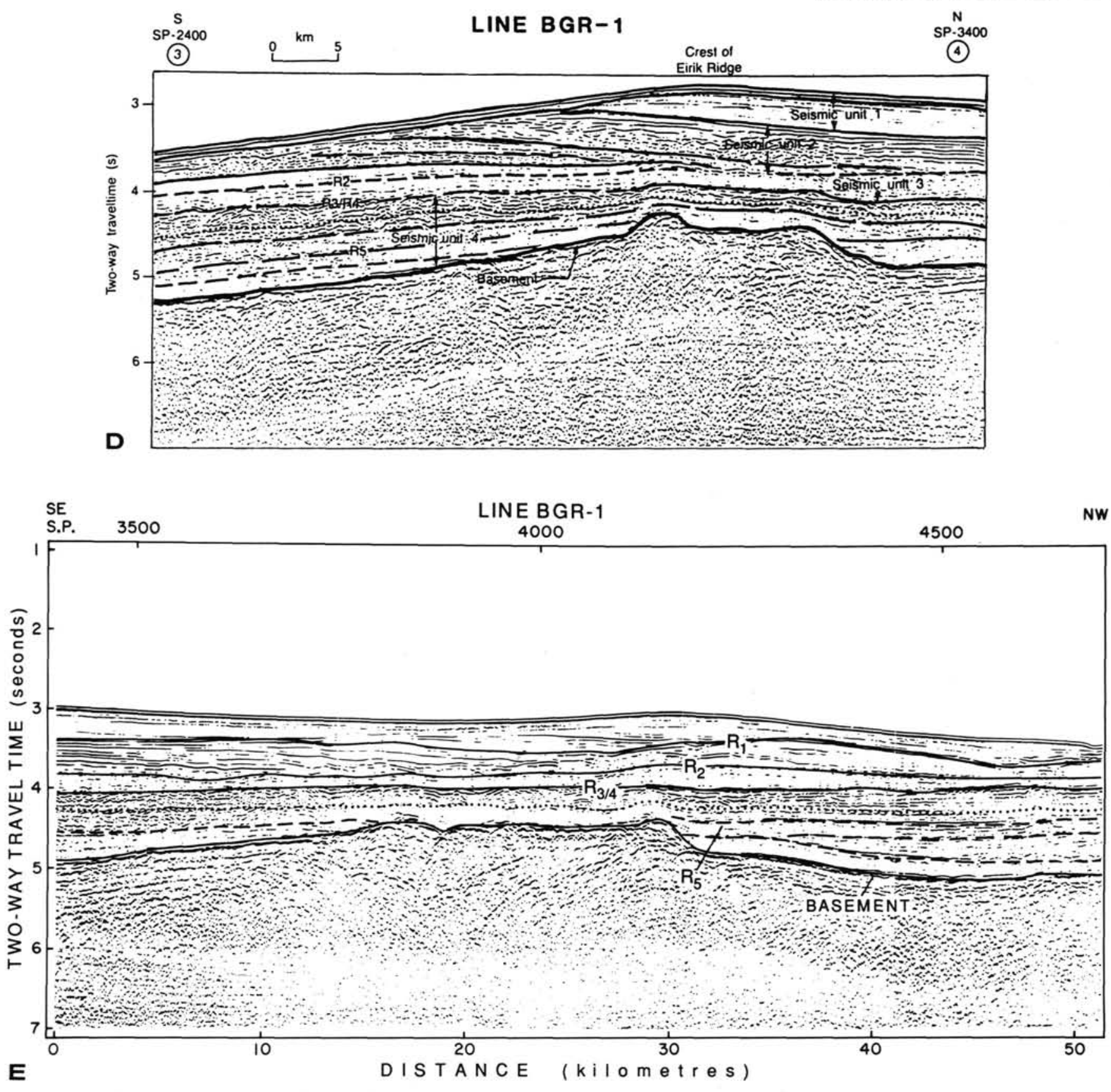

Figure 7 (continued).

thetic seismogram (Fig. 9), even though no such return is seen in the real seismograms.

The characteristics of the source function (amplitude, frequency content, and shape) can have a large effect on the seismogram generated. To produce a representative synthetic seismogram, it is critical that the characteristics of the source function used in an experiment be known. Unfortunately, no hydrophone record of the near-field or far-field source signature is available. As an alternative, a synthetic seismogram generated using a 50$\mathrm{Hz}$ Ricker wavelet was constructed. Ten traces are superimposed on the BGR-12 multichannel seismic-reflection profile, which runs along an east-west transect (Figs. 3, 6, and 9). The synthetic seismogram does well when matching the character of the reflection profile, except in the interval between 100 and 206 mbsf and for the deepest reflectors.

\section{Seismic Sequence 1: Upper Pliocene-Pleistocene}

Seismic sequence 1 , the uppermost of the seismic sequences, varies in thickness from 0.20 to $0.40 \mathrm{~s}$ in the region adjacent to Site 646 (Fig. 9). At this site, the sequence is about $0.28 \mathrm{~s} \mathrm{(236}$ $\mathrm{m})$ thick and comprises moderate- to high-amplitude subparallel reflectors. The thinnest part of the sequence occurs at the subsidiary ridge just south of Site 646. At this point, the amplitude of the reflectors also decreases somewhat. The base of this seismic sequence lies at a depth of about 236 mbsf, marked by a very high-amplitude reflector, R1. R1 probably corresponds to the bottommost occurrence of ice-rafted debris, including dropstones ( $238 \mathrm{mbsf}$ ). Seismic sequence 1 consists predominantly of silty clays and clayey silts and minor amounts of biogenic components, with some sandy layers in the lower part (see Hiscott et 


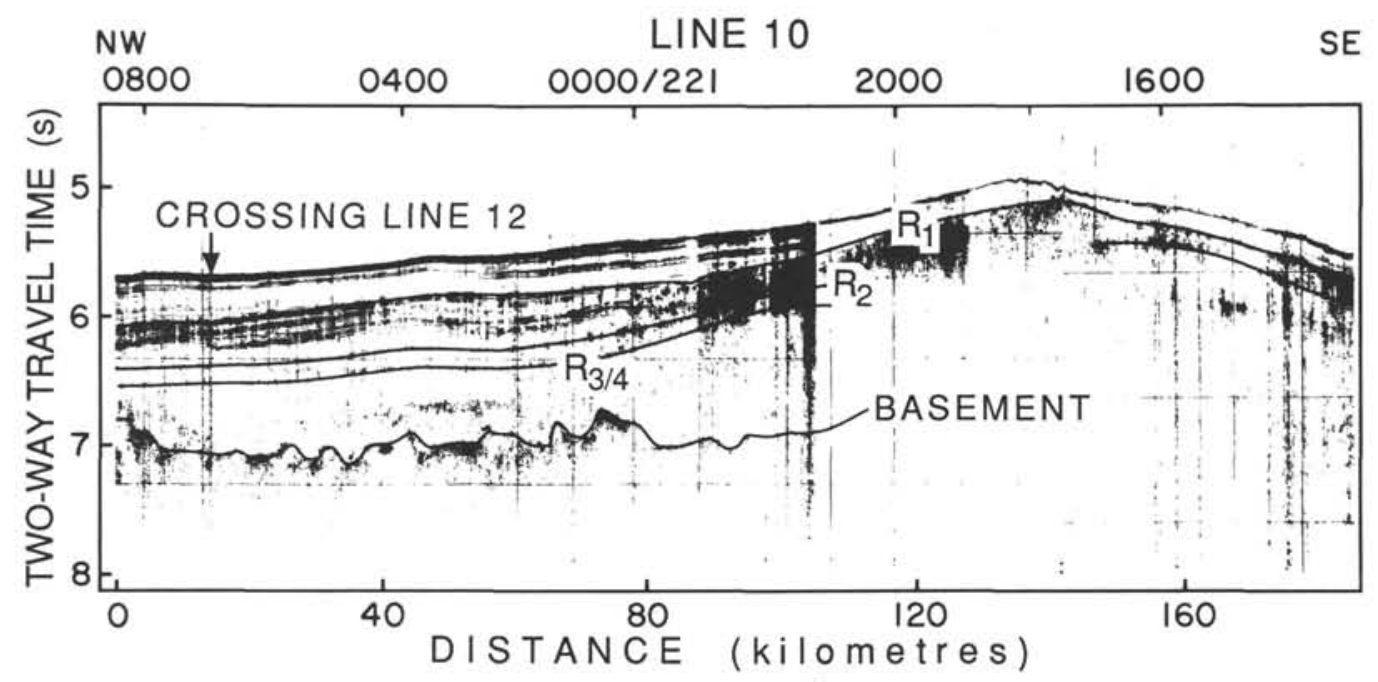

Figure 8. Hudson single-channel seismic-reflection record across Eirik Ridge (see Fig. 3 for location). This line ties into Site 646 at its northwestern end. Note discontinuity at reflector R1.

al., this volume; Cremer, this volume). The prominent multiple reflectors seen throughout this interval probably arise from local variations in the relative proportions of carbonate and clay. A change in density and porosity at the Pleistocene/Pliocene boundary leads to a moderate-amplitude reflector at about 125 mbsf. Similarly, a marked change in the rate of decrease of water content and porosity and increase in density with depth at 75 mbsf correlates well with the occurrence of a pronounced reflector at this depth. Reflectors generally are much more prominent in the upper Pleistocene part of seismic sequence 1.

The bottom of seismic sequence 1 at 236 mbsf is conformable with the top of seismic sequence 2 at the drill site (Figs. 5, 9, and 10); however, south and east of the site, the two sequences are separated by an unconformity where the basal reflectors onlap the top of seismic sequence 2 (Fig. 10). The southern end of line 14 in Figures 5 and 10 clearly shows an unconformity marked by a prominent reflector (R1) between the two units at the base of an erosional depression.

General smoothing and continuous sedimentation of the drift sequence occurred during the late Pliocene through the Pleistocene, but with differential sedimentation on the lee sides of the ridges (Figs. 5, 6, 7, and 8). No distinct break in sedimentation occurs either in the cores from Site 646 or in the seismic lines associated with the Pliocene/Pleistocene boundary. However, there is a major turnover in benthic foraminifers that brackets the boundary, suggesting a water-mass change (Kaminski et al., this volume) at that time. The age of the first recognizable ice rafting agrees with that established for the northeastern Atlantic (Shackleton et al., 1984) and for the major ice rafting in the Norwegian Sea (Eldholm, Thiede, Taylor, et al., 1987) but is considerably younger than that found at Site 645 in Baffin Bay (Srivastava, Arthur, et al., 1987; Korstgard and Nielsen, this volume).

\section{Seismic Sequence 2: Lower to Upper Pliocene}

Seismic sequence 2 consists of many very high-amplitude, parallel-to-subparallel reflectors between 0.27 and $0.45 \mathrm{~s}$ mbsf (about 230-382 mbsf) at Site 646 and thickens to the south, where it reaches a maximum thickness of $0.27 \mathrm{~s}$ (about $270 \mathrm{~m}$ ). Seismic sequence 2 has a lenticular shape and comprises a series of slightly northward-dipping, subparallel reflectors near the site on line 14 (Fig. 5). Thicknesses between individual reflectors vary systematically. At some places, migrating sediment waves are visible, indicating a strong influence of bottom currents on the deposition of sediments (Fig. 7E). Seismic sequence 2 may have been deposited during a massive influx of sediments-the result of the same depositional regime that produced the pronounced depositional ridge seen in lines 14, 10, and BGR-1 (Figs. 5, 7, and 8). Seismic sequence 2 is predominantly composed of silty clays and clayey silts, with subordinate, relatively nannofossil-rich beds equivalent to the upper part of lithologic Unit II (Fig. 5). The bottom of seismic sequence 2 lies conformably on top of seismic sequence 3 near Site 646, but in general seismic sequence 2 is separated from the underlying seismic sequence 3 by an erosional unconformity. The seismic expression of the sequence $2 /$ sequence 3 contact suggests an irregular thickness of the upper part of seismic sequence 2 above reflector $\mathrm{R} 2$ and indicates possible erosion at the seismic sequence $2 /$ sequence 3 contact (Figs. 5 and 6). However, no evidence of a hiatus was found at Site 646 .

Seismic sequence 2 comprises sediments of lower-to-upper Pliocene age. Sonic logs exhibit only small changes in velocity in this interval, but substantial reflectors were generated in the synthetic seismogram (Fig. 2). One of the most significant reflectors occurs at about $340 \mathrm{mbsf}(0.40 \mathrm{~s}$; see Fig. 9). This reflector most likely represents a pronounced change in sediment physical properties that result from an increase in the proportion of diatoms and radiolarians above and an increase in carbonate content below. This event occurs within the lower Pliocene (ca. 4.0 Ma). Biosiliceous material is common to abundant in the upper Pliocene, whereas calcareous nannofossils and planktonic foraminifers are more abundant in the lower Pliocene. This change in dominance of planktonic biota probably represents significant cooling of surface-water masses near the site, accompanied by possibly higher productivity of siliceous plankton. This surface-water event occurred somewhat later than a period of apparent intensification of deep circulation (see below), which marks the base of seismic sequence 2 at about 4.5 Ma. Erosional modification of the drift sequence, construction of a pronounced ridge observed in the regional seismic lines (Figs. 5, 6, and 7), and changes in sediment average grain size and sorting (e.g., Cremer, this volume) occur at this horizon. A decrease in sedimentation rate also may occur from the base of seismic sequence 2 at about 380 to $390 \mathrm{mbsf}$ to about $340 \mathrm{mbsf}$ (Jarrard and Arthur, this volume), which may explain the higher carbonate contents and stronger cyclicity in this interval (Fig. 9). This major change in character of sedimentation at about 4.5 Ma also was accompanied by a change in benthic foraminif- 


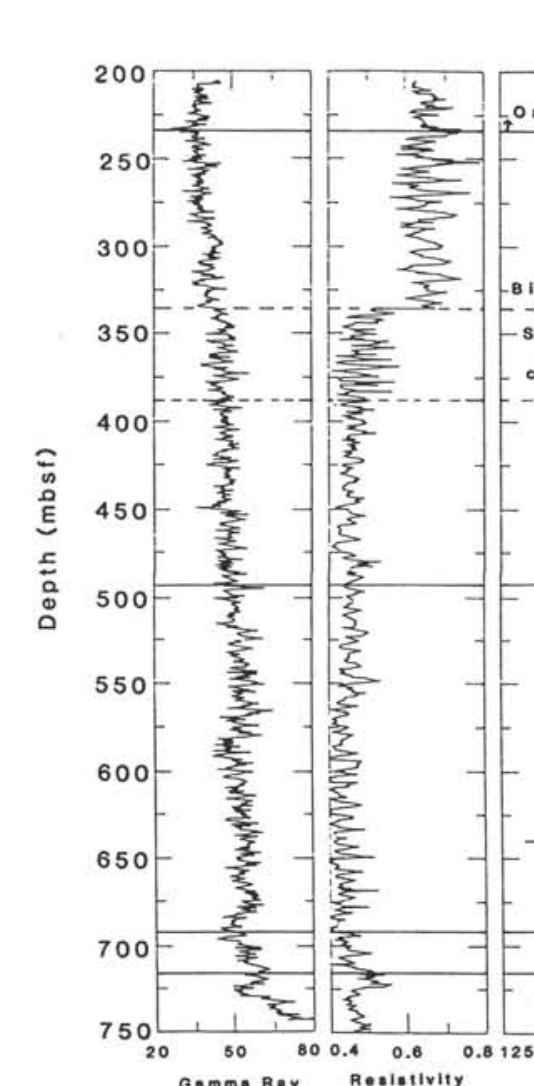

Gamma Ray

porosity
SITE 646

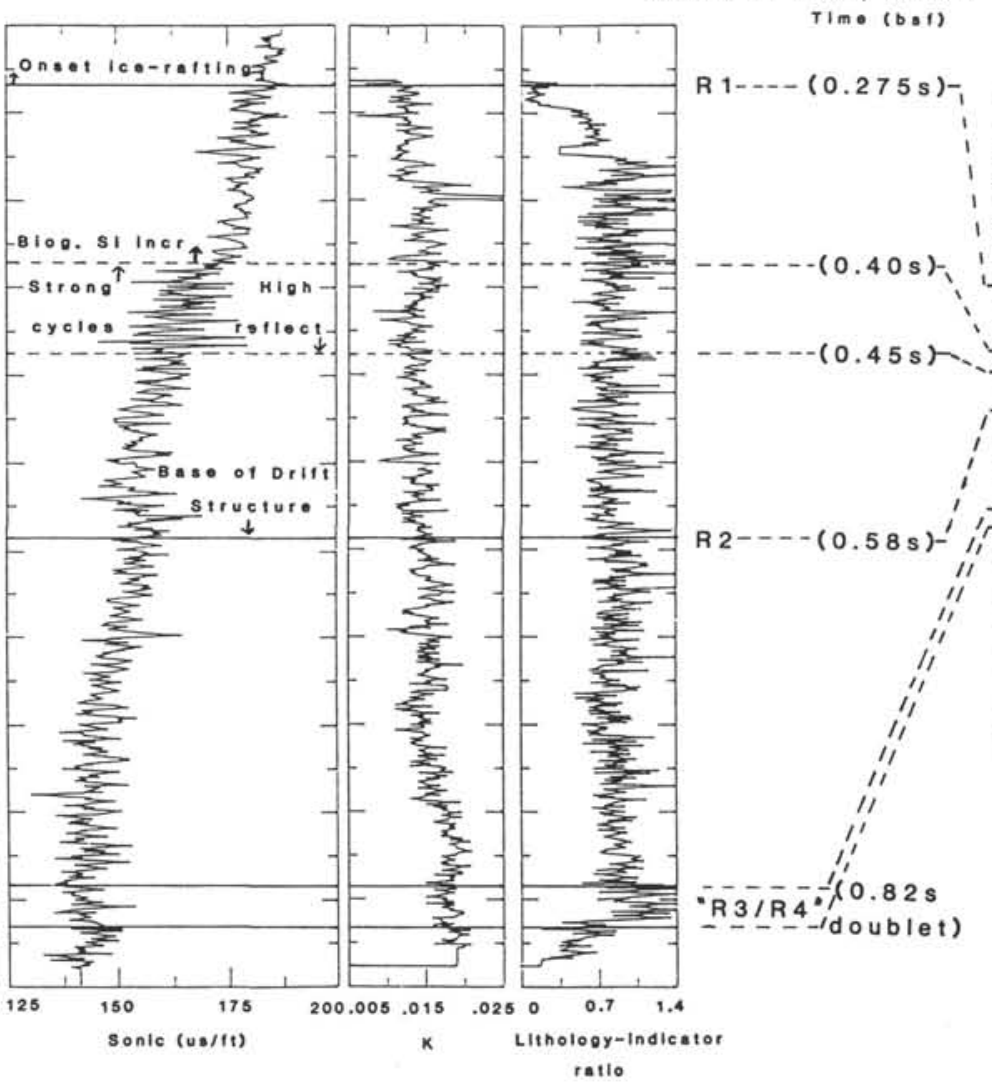

ratlo
Two-way travel time (s)

Figure 9. Segment of multichannel line BGR-2 (Site 646 location projected onto it from $16 \mathrm{~km}$ to the north via ties to single-channel line 14 ) showing synthetic seismogram (see text), reflectors an seismic sequences (units $1,2,3,4$ ) and correspondence of reflectors to changes in physical properties measured by geophysical logging techniques. 


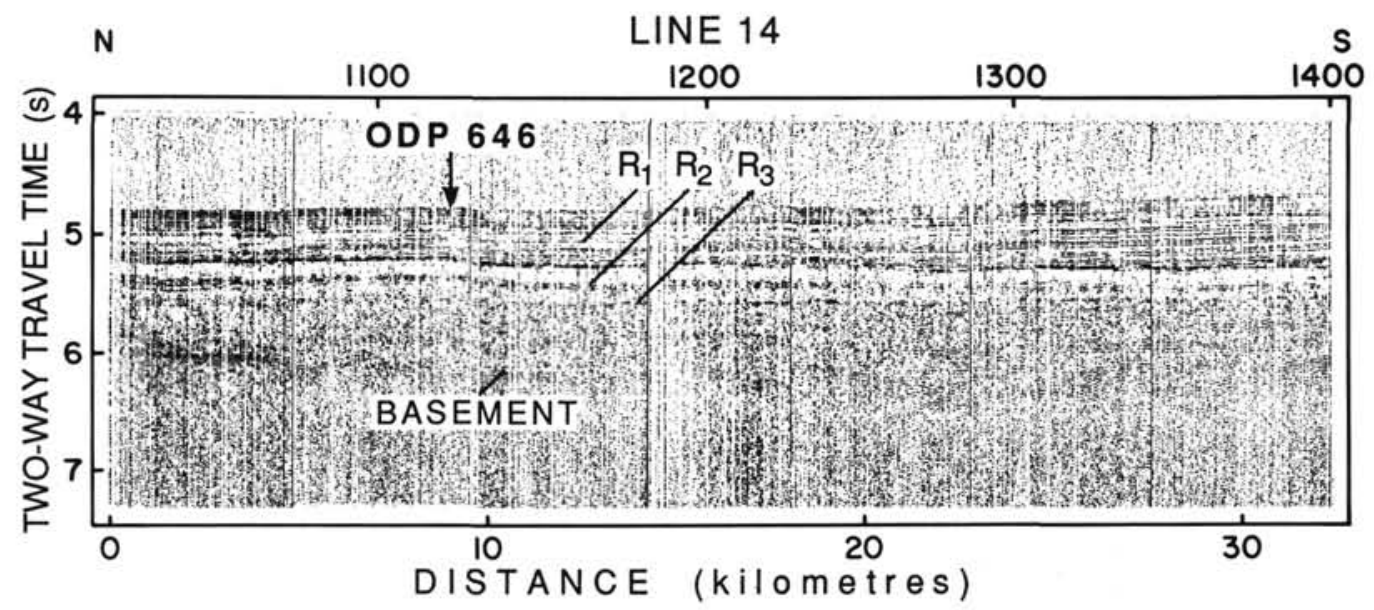

Figure 10. Entire trace of Hudson single-channel seismic-reflection line 14 (see Fig. 3 for location) showing possible erosional unconformity and onlap at base of the strongly seismically laminated drift sequence south of Site 646 (between R1 and R2).

eral assemblages, from coarse, agglutinated benthics and $R h i$ zammina below to a more calcareous "NADW"-type assemblage above (see Fig. 12; Kaminski et al., this volume).

Deposition of seismic sequence 2 in the early Pliocene marked a distinct change in sedimentation in the region. The base of seismic sequence 2 lies unconformably above seismic sequence 3 over much of the area, except in the lee of the depositional ridges, such as at Site 646 , where sedimentation was apparently continuous across the contact between the two units (Figs. 5 and $10)$. Buildup of these pronounced depositional ridges may have occurred mainly during the early to early-late Pliocene. The seismic line across the Eirik Ridge (Fig. 6) exhibits an unconformity between seismic sequences 2 and 3 . Strata of seismic sequence 2 apparently climbed the slope at the top of seismic sequence 3 and progressively built a large dune that began to prograde northward across the present position of Eirik Ridge (see also Figs. 6, 7). The southern part of the BGR-1 line (Figs. 7A and 7B) shows that seismic sequence 3 was partially eroded before or during deposition of seismic sequence 2. A major flood of sediment (probably from the source region of the IMOC) also occurred during deposition of seismic sequence 2 . The increase in sediment supply was observed at DSDP Site 113 in the form of Pliocene turbidites deposited at rates of $35 \mathrm{~cm} / \mathrm{k} . \mathrm{y}$. and equivalent in age to our seismic sequence 2 . The high rate of sediment supply, coupled with apparently increased current velocities, may have caused the episode of drift construction. Later, erosional modification of the drift sequence in the upper part of seismic sequence 2 occurred during the late Pliocene (Figs. 5, 6, and 7). Several seismic lines show that large sediment waves formed at this time concomitant with the erosional episode (Fig. 7). The sediment erosion and formation of sediment waves might have been the result of a decrease in sediment supply and/or an increase in current velocities (e.g., Mountain and Tucholke, 1985). We discuss this possibility in a later section of this chapter.

\section{Seismic Sequence 3: Upper Miocene-Lower Pliocene}

Seismic sequence 3 consists of continuous-to-discontinuous reflectors. The single-channel profiles exhibit low-amplitude reflectors compared with those in seismic sequence 2 . However, multichannel records are characterized by reflectors of moderate amplitude (Figs. 6, 9). Seismic sequence 3 lies conformably to unconformably over seismic sequence 4 , as seen in these multichannel data. Such character is difficult to see in the singlechannel data because of the lack of resolution through this in- terval. The calculated depth to $\mathrm{R} 2$, an important regional reflector, lies at a depth of $0.13 \mathrm{~s}$ from the top of seismic sequence 3 , or at a depth near 480 mbsf. Density and porosity measurements exhibit only minor variations within seismic sequence 3 and can be related to the changes in the amplitude of the resulting reflectors (Fig. 9). The base of Unit III is marked by the presence of a high-amplitude reflector doublet that is underlain by many diffractions and is interpreted here as being the R3/R4 reflector at about 680 mbsf.

Deposition of seismic sequence 3 occurred during the late Miocene and earliest Pliocene. A short-term decrease in the rate of sedimentation takes place at about 680 to $670 \mathrm{mbsf}$ (Baldauf et al., this volume) associated with the changes in physical properties that probably induce the R3/R4 reflector (Fig. 9). There may be a hiatus of variable duration associated with the R3/R4 reflector over the region, which may have been caused by erosive currents. However, the thickness of seismic sequence 3 is constant over the region, except where erosion of the upper part has taken place. The R2 reflector occurs at 480 mbsf and lies just below the Miocene/Pliocene boundary. This reflector probably represents a subtle lithologic change, mainly an increase in carbonate content above (see Figs. 11 and 12 and Jarrard et al., this volume) in the uppermost Miocene section. No evidence of an erosional hiatus at R2 exists either at Site 646 or in the seismic lines. Although deposition took place at high rates $(96 \mathrm{~m} /$ m.y.) during the late Miocene, there is no direct seismic evidence of formation of a depositional ridge at this time. The high sediment-accumulation rates and the lithologic and textural similarity of strata from the upper part of seismic sequence 3 , along with those of seismic sequence 2 , suggest that deposition was controlled by bottom currents, but that these were not particularly strong. The R2 reflector at about 480 to 490 mbsf (ca. 5.45.6 Ma) may mark an increase in carbonate preservation (Fig. 12) and probably corresponds to a similar carbonate-rich horizon observed at Leg 94 sites in the eastern Atlantic (e.g., Hooper and Weaver, 1986). Significant changes in textural characteristics (Cremer, this volume) suggest such an intensification of deep currents at this time as well.

\section{Seismic Sequence 4: Lower Eocene(?)-Upper Miocene}

Seismic sequence 4, the top of which lies at a depth of $0.82 \mathrm{~s}$ at Site 646, extends downward to the top of the fairly prominent basement reflector that is the top of the oceanic crust at roughly $1.3 \mathrm{~s}$ near Site 646 . The top of seismic sequence 4 is marked by the R3/R4 reflector, which is actually two strong reflectors sep- 

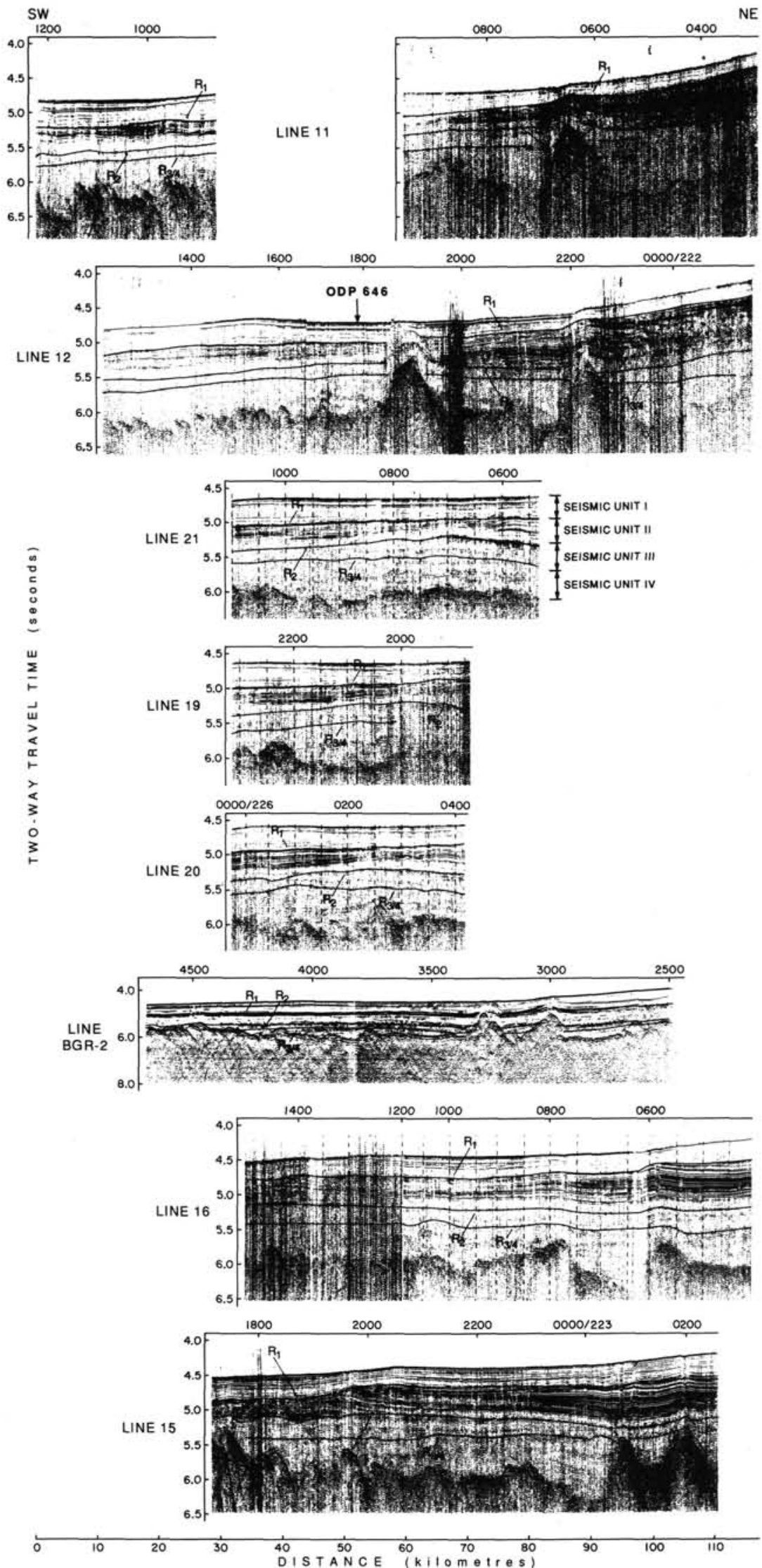

Figure 11. Series of seismic-reflection profiles that cross the axis of the small subsidiary ridge on the northern flank of Eirik Drift. Lines are arranged from north (line 11) to south (line 15). Note reflective drift morphology between R2 and R1, with erosion at R1 and subsequent "smoothing" of the drift. 


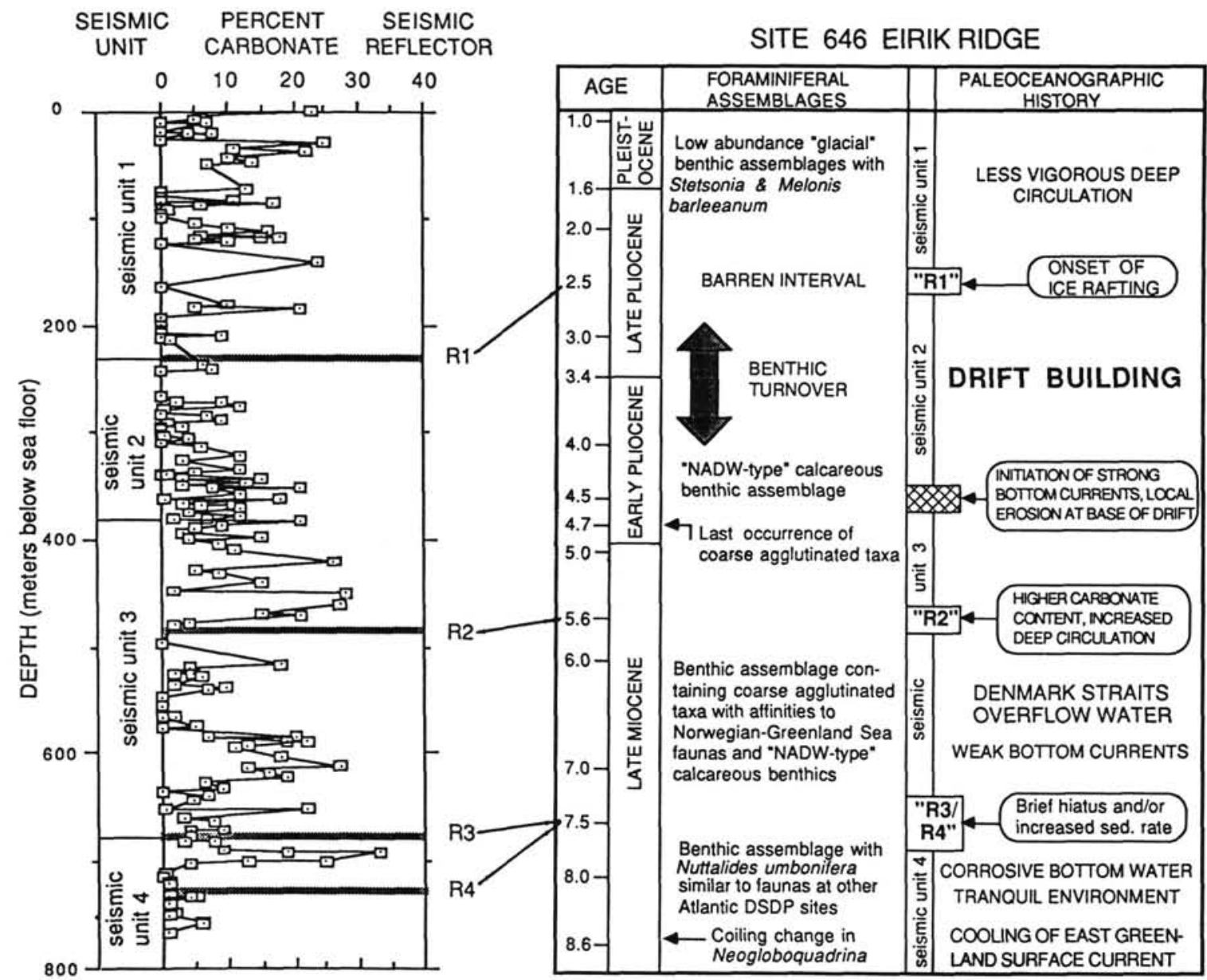

Figure 12. Carbonate stratigraphy, seismic sequences and reflectors, and benthic foraminiferal events and inferred paleoceanographic history at Site 646 on Eirik Drift.

arated by about $0.05 \mathrm{~s}$. We think that we recovered only the top 80 to $90 \mathrm{~m}$ of seismic sequence 4 below the first reflector of the R3/R4 doublet at Site 646 . No marked lithologic change occurs in the interval from 680 to $730 \mathrm{mbsf}$, although sharp changes occur in carbonate content and physical properties at $680 \mathrm{mbsf}$, and carbonate content decreases sharply to $<5 \%$ below 695 mbsf (Figs. 9 and 12).

The synthetic seismogram exhibits two high-amplitude reflectors near 680 and 730 mbsf (Fig. 9). The character of the generated pulse is similar to that of the top of R3/R4 reflector and to a companion reflector (R3/R4) that consistently occurs in the multichannel seismic lines at about $0.05 \mathrm{~s}$ deeper than the main R3/R4 reflector (Fig. 9). These data strongly support the contention that we drilled through and dated the R3/R4 reflector. Micropaleontologic studies indicate important changes in the benthic fauna over the interval of 650 to 670 mbsf (Kaminski et al., this volume) and in preservation and abundance of calcareous planktonic microfossils at $670 \mathrm{mbsf}$ (Aksu and Kaminski, this volume).

A large hiatus probably exists in the sequence beneath the base of Hole 646B. From the age of the crust that underlies this region (Chron 24, 55-56 m.y.) and the constraint on the youngest age imposed by our drilling results, seismic sequence 4 should contain sediments from upper Miocene to lower Eocene in age. However, the average sedimentation rates must be much lower than that indicated in the lower part of seismic sequence 3 $(49-90 \mathrm{~m} / \mathrm{m} . \mathrm{y}$.) or a significant hiatus must exist in seismic se- quence 4. A prominent reflector (R5) lies at a depth of $1.25 \mathrm{~s}$ within this unit (Fig. 9) and terminates to the west against a basement high of early middle Eocene age, as obtained from magnetic-anomaly identification. This reflector may correspond to the R4 reflector of Masson and Kidd (1986; see later discussion) and Miller and Tucholke (1983) in the northeast Atlantic. Drilling results clearly show that the reflector R3/R4 previously identified by Miller and Tucholke (1983) is not older than early late Miocene and is not equivalent to the R4 reflector of the northeast Atlantic.

\section{Site 647: Paleogene-Neogene Record on Southern Gloria Drift}

Seismic lines and drilling results at Site 647 can provide insight into the timing and processes of construction of Gloria Drift (Egloff and Johnson, 1975) in the southern Labrador Sea. Below, we outline the salient features of seismic stratigraphy and age correlations for the Gloria Drift region (Fig. 1) as they bear on the history of deep circulation in the southern Labrador Sea.

Site 647 is at the intersection of HD 84-30 lines 8 and 6 (see Fig. 13). These and other lines that lie near this site (Fig. 13) exhibit several prominent reflectors (Fig. 14). The reflector sequence has been grouped into three discrete seismic sequences, based on reflector uniformity, continuity, and characteristics. DSDP Site 112, which was drilled during DSDP Leg 12, lies about $100 \mathrm{~km}$ northwest of Site 647, and these two sites can be compared using the seismic lines that cross them. 

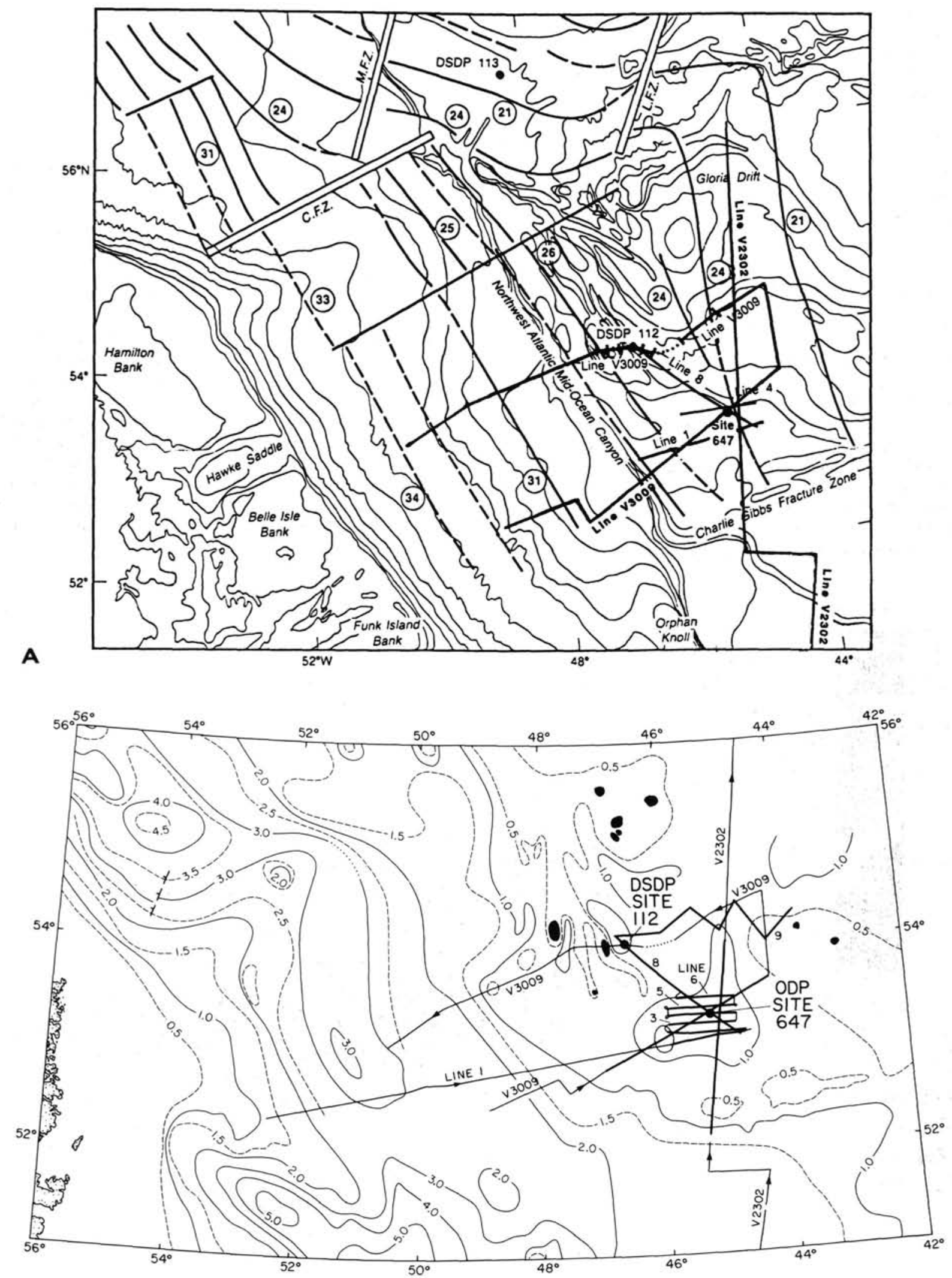

B

Figure 13. A. Generalized bathymetry on and around Gloria Drift showing locations of Charlie-Gibbs Fracture Zone, the Northwest Atlantic Mid-Ocean Channel and magnetic anomalies, as well as DSDP Sites 112 and 113, ODP Site 647, and selected seismic-reflection lines discussed in the text. B. Enlargement of southwestern portion of Gloria Drift showing Sites 647 and 112 and important seismic-reflection lines discussed in the text. Contours are sediment thickness in seconds of two-way traveltime. 
For calculating the depth of each reflector, we used an average velocity of $1.62 \mathrm{~km} / \mathrm{s}$ for the first two sequences (above $0.32 \mathrm{~s}$ two-way traveltime) and $2.0 \mathrm{~km} / \mathrm{s}$ for seismic sequence $3(0.32$ $0.77 \mathrm{~s}$ two-way traveltime), as obtained from physical-property measurements (Jarrard et al., this volume). A synthetic seismogram based on these physical-property measurements exhibits impedance contrasts and reflectors of varying amplitude that match reasonably well with the reflectors observed in the seismic profiles (Srivastava, Arthur, et al., 1987). Correlation of the calculated reflector depths from the seismic-reflection lines with changes in lithofacies, physical properties, and biostratigraphy is shown in Figure 14.

\section{Seismic Sequence 1: Upper Pliocene-Pleistocene}

Seismic sequence 1 is about $0.12 \mathrm{~s}$ thick at Site 647 and is composed of a series of moderate- to high-amplitude reflectors that are parallel to the seafloor (Figs. 14, 15). The unit varies in thickness over the nearby region and has a maximum thickness of about $0.3 \mathrm{~s}$ west and south of Site 647 (Fig. 13B), presumably because of the supply of clastic sediment from the North Atlantic mid-Ocean Channel (NAMOC) to the west (Fig. 13A). Reflectors within the sequence are generally parallel to subparallel, except in regions where the unit thickens to the west-southwest. In these thicker regions, the lower reflectors onlap the top of seismic sequence 2 (see Figs. 15A, 15B). The base of seismic sequence 1 is characterized by a strong, continuous-to-discontinu- ous reflector, termed $\mathrm{R} 2$, that may represent an unconformity, as indicated by the onlap of seismic sequence 1 strata.

The R2 reflector at the base of seismic sequence 1 corresponds to the top of lithologic Unit II, which is of lower to upper Miocene age and consists mainly of silty mud, clay and nannofossil clay, as well as silica-bearing clays lacking calcareous nannofossils in the lower part. A prominent hiatus, encompassing the interval between $2.5 \mathrm{Ma}$ and 5.6 to $8.2 \mathrm{Ma}$ occurs between lithologic Units I and II. Reflector R2 corresponds to this hiatus and, therefore, does represent a major unconformity. Unfortunately, the results of Site 647 studies cannot precisely constrain the age of R2 because of another prominent hiatus spanning the 8.2 - to $17.5-\mathrm{Ma}$ interval, only $3 \mathrm{~m}$ below the late Miocene-Pliocene hiatus.

The sediments of seismic sequence 1 and lithologic Unit I are terrigenous in nature. Recognizable alternations of relatively nannofossil-rich silty clay and more gravel-rich, silty intervals marking glacial-interglacial climatic cycles form the main part of this seismic sequence. Both bottom-current, winnowed beds enriched in biogenic components and turbiditic, detrital carbonate-rich sediment derived from spillover from the NAMOC also are present (Hiscott et al., this volume). What causes prominent reflectors within seismic sequence 1 is uncertain, but the synthetic seismogram shows that some of the reflectors arise from variations in density as the result of changes in relative proportions of carbonate and terrigenous materials (Srivastava, Arthur, et al., 1987).

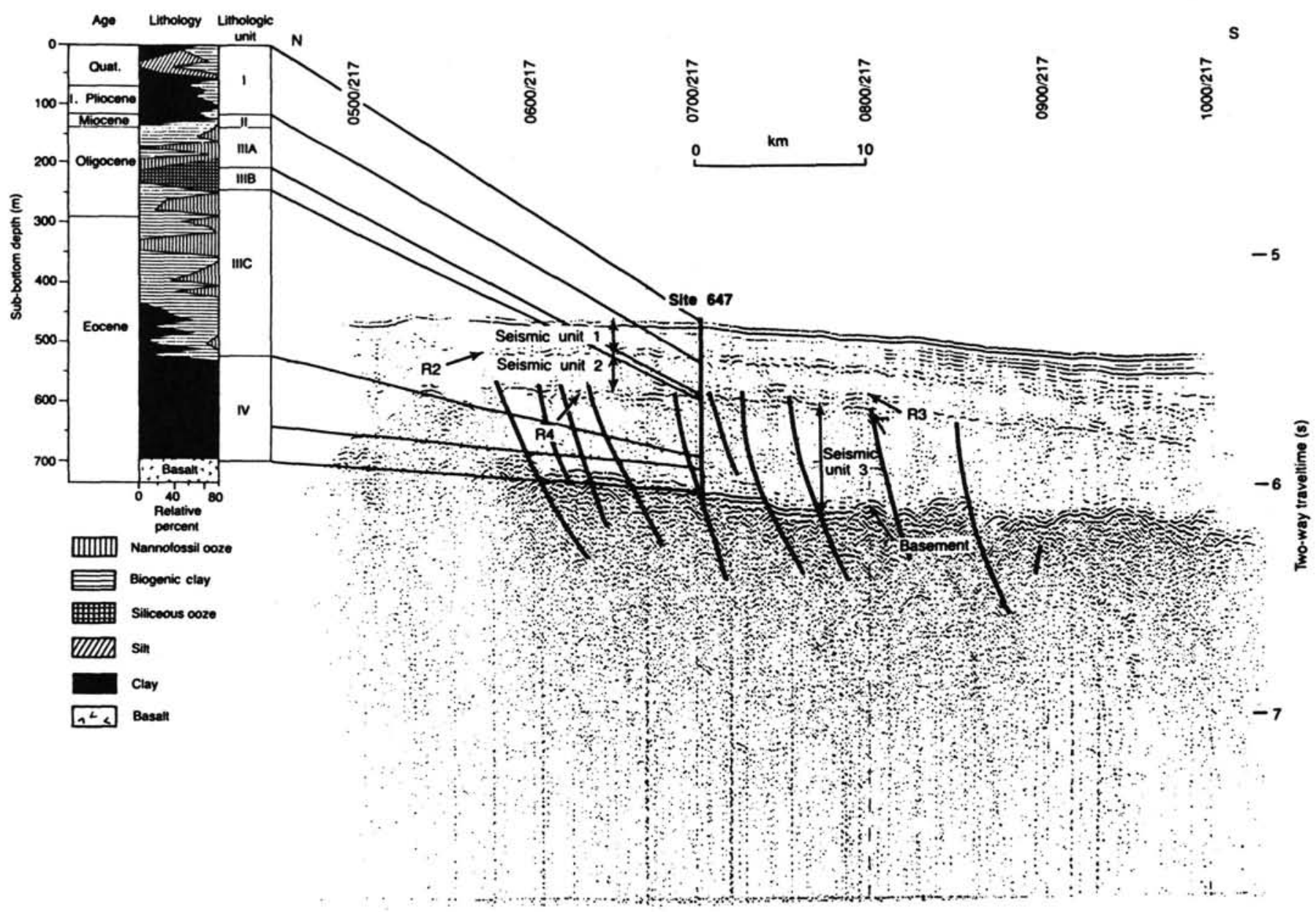

Figure 14. Segment of Hudson single-channel reflection line 8 across Site 647 on southwestern flank of Gloria Drift with ties of reflectors and seismic sequences from seismic record to the lithologic sequence recovered in Site 647 . 

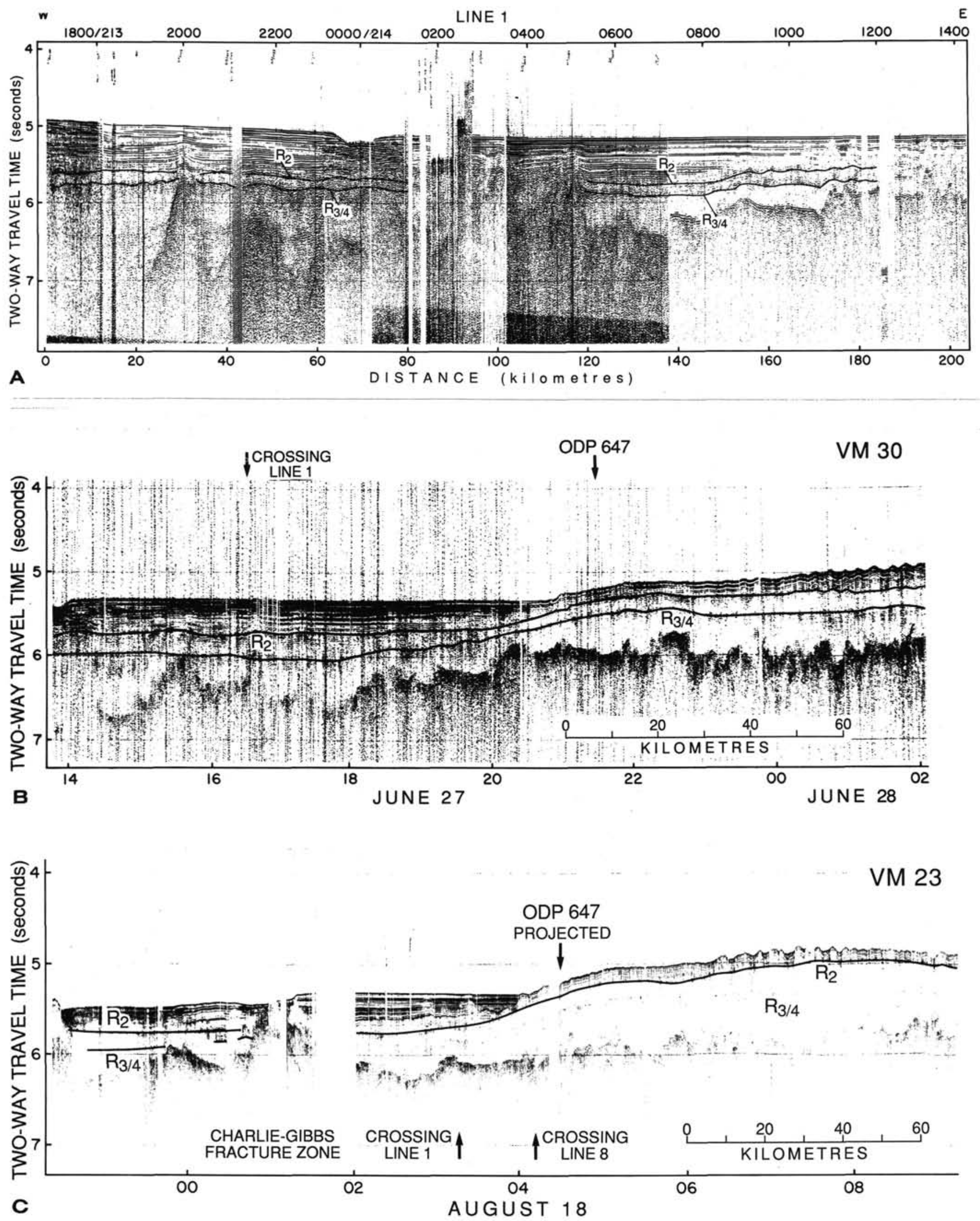

Figure 15. Seismic-reflection lines Hudson line 1 (A), and Vema lines VM30 (B) and 23 (C) crossing the NAMOC that runs to the west of Gloria Drift (see Fig. 13 for locations). Reflector R2 appears to mark the base of the reflective NAMOC sequence, which is characterized mainly by turbidites. 
Over the last 2.5 m.y. of deposition (Unit I; late PliocenePleistocene), recognizable alternations of relatively nannofossilrich, silty clay and more gravel-rich, silty intervals may represent depositional cycles related to glacial-interglacial climatic cycles. Average sedimentation rates are about $46 \mathrm{~m} / \mathrm{m}$.y. As at Site 647 , the earliest evidence of glacial ice rafting occurred at about 2.5 Ma. Sediment deposited over the last 1.2 m.y. contains more silt, sand, and detrital carbonate than does the older part of Unit I.

\section{Seismic Sequence 2: Lower Oligocene-Lower Pliocene}

Seismic sequence 2 occurs between 0.12 and $0.32 \mathrm{~s}$ at Site 647 , but it varies between 0.15 to $0.35 \mathrm{~s}$ thick over the region. In the seismic record across Site 647, the sequence appears transparent, except for one fairly prominent reflector near the base (at about 240 mbsf). Northwest of Site 647, near DSDP Site 112 , the same reflector lies in the middle of seismic sequence 2 (Fig. 16). The base of seismic sequence 2 is marked by a highamplitude, continuous-to-discontinuous reflector, which is the most prominent reflector traceable throughout the region. The equivalent reflector was drilled at DSDP Site 112, about $100 \mathrm{~km}$ northwest of Site 647 (Fig. 13), and was called a mid-sediment reflector and assigned a middle Oligocene age by Laughton, Berggren, et al. (1972; Berggren, 1972). Miller and Tucholke (1983) later identified this as the R3 or R4 reflector of mid-early Oligocene age and argued that it is equivalent to the OligoceneEocene R4 reflector in the northeast Atlantic. Correlation with lithologic units at Site 647 suggests that seismic sequence 2 corresponds to lithologic Units IIIA and IIIB (134-240 mbsf). Thus, the age of seismic sequence 2 is lower Oligocene through upper Miocene.

A condensed sedimentary sequence characterizes early-tolate Miocene deposition (Unit II), and at least one hiatus occurs between the upper Miocene $(8.2 \mathrm{Ma})$ and the lower Miocene (17.5 Ma). Iron/manganese and phosphate nodules, streaks, and bands characterize much of the interval. The hiatuses and slow sedimentation, $<1 \mathrm{~m} / \mathrm{m}$.y. for the intervening interval (116-119.3 mbsf), probably indicate scour by strong bottom currents and/or nondeposition in conjunction with low sediment supply during much of the early-to-late Miocene. An additional hiatus of $7.0 \mathrm{~m} . \mathrm{y}$., or very slow sedimentation, may be present between the lower Miocene and upper Oligocene between Cores 105-647A-14R and 105-647-15R (135 mbsf; Baldauf et al., this volume).

Lithologic Subunits IIIA and IIIB contain mainly bioturbated biogenic claystones and clayey ooze, which are predomi- nantly nannofossil rich, but which also contain varying amounts of biogenic opal in the lower Oligocene part (Fig. 17). The lower Oligocene strata between 212.3 and 241.1 mbsf are rich enough in biogenic opal to be considered diatomites. Sonic velocity measurements from discrete samples in lithologic Subunits IIIA and IIIB exhibit a decrease from those obtained in sequence 1 (Jarrard et al., this volume). A similar behavior also can be seen in the density values. The largely transparent nature of seismic sequence 2 , which persists on a regional basis, probably relates to the consistently low densities and velocities observed in this interval. This sequence is devoid of any hiatuses that could be regarded as unconformities. Thus, the only prominent lithologic boundary that can be matched to the calculated depth to reflector R4 is the change from biosiliceous (above) to calcareous biogenic claystones (below; see Fig. 17). The reflector thus appears to bear no direct relationship to changes in rate of bottom-water circulation.

\section{Seismic Sequence 3: Lower Eocene-Lower Oligocene}

Seismic sequence 3 , the deepest sequence defined in the records crossing Site 647 (Figs. 14, 16) lies below $0.32 \mathrm{~s}$ and extends to the top of the fairly prominent basement reflector that marks the top of the oceanic crust at a depth of about $0.77 \mathrm{~s}$ near the site. Except for a few reflectors near the bottom of the sequence that have attitudes conformable with the inferred basement surface, the sequence is more or less transparent, but has higher reflectivity than seismic sequence 2 . The bottommost reflector in seismic sequence 3 abuts against the basement highs.

Correlation of this sequence with lithology at Site 647 (Figs. $14,17)$ shows that it encompasses strata belonging to lithologic Subunit IIIC and IV (240-699 mbsf) and, therefore, is early Eocene to early Oligocene in age. Sediments within Subunit IIIC are similar to those in the overlying lithologic units, except that they contain little biogenic silica and are rich in calcareous nannofossils. One of the reflectors lying near the base of seismic sequence 3 appears to correspond in depth to the base of lithologic Subunit IIIC (525 mbsf; see Fig. 17).

The seafloor at Site 647 apparently subsided to abyssal depths during the early Eocene, as reflected in the benthic foraminiferal assemblages (Kaminski, Gradstein, and Berggren, this volume). During the time corresponding to early Eocene nannofossil Zone NPl3 (53.6-52.6 Ma), the carbonate compensation depth (CCD) at the site rose, resulting in the deposition of variegated (red and green) noncalcareous claystones within lithologic Unit IV. The CCD descended during the early middle Eocene (nannofossil Zone CPI3b; 48.7-47.0 Ma) as indicated by

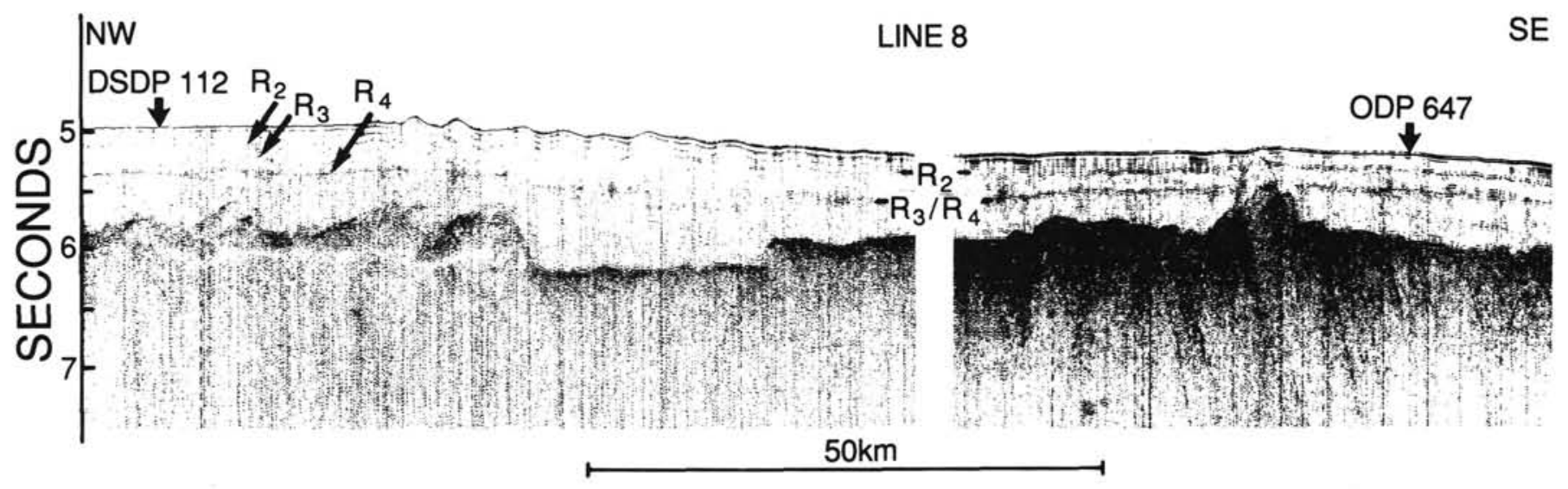

Figure 16. Hudson line 8, which connects ODP Site 647 and DSDP Site 112 to the northwest on Gloria Drift. Sediment waves and strong reflections characterize sequence only above $\mathrm{R} 2$. 


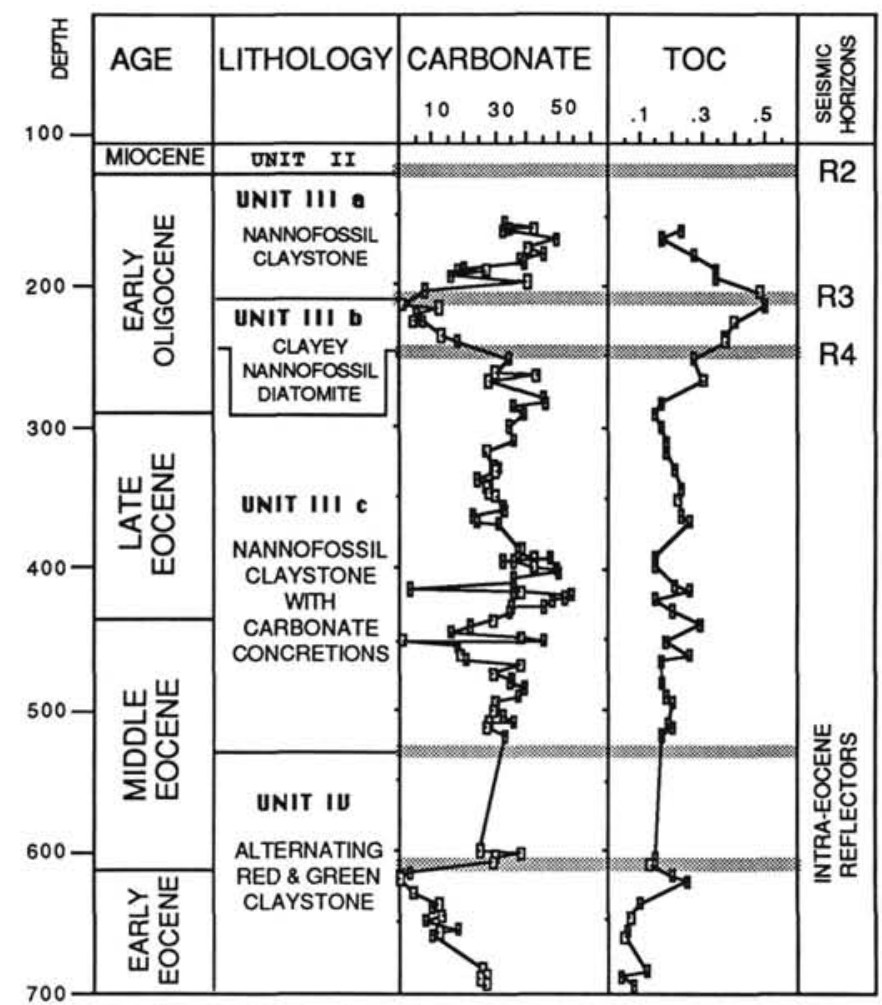

Figure 17. Site 647 lithologic units and ages with $\mathrm{CaCO}_{3}$ and TOC (organic carbon) values shown as well as major reflector correlations to lithologic units discussed in text.

the return to biogenic carbonate-rich facies and fair-to-good preservation of calcareous microfossils. The $\sim 20$-m interval, which consists of noncalcareous lithofacies, is devoid of biostratigraphically useful planktonic microfossils and represents a condensed horizon that may include one or more hiatuses spanning approximately 3.9 to $6.6 \mathrm{Ma}$. The variegated claystones contain a characteristic benthic foraminiferal assemblage dominated by the genus Glomospira, which is also found in deep-water strata of equivalent age in the Alpine region and at Site 643 in the Norwegian-Greenland Sea. A climatic optimum characterized by highest diversity of calcareous plankton occurred during the late middle Eocene (about $41 \mathrm{Ma}$ ).

\section{Site 645: Neogene Record Along the Western Margin of Baffin Bay}

Seismic sequences were defined on the basis of a network of multichannel lines for the region near Site 645 in western Baffin Bay (Figs. 2, 18). A basic description is provided below, along with our interpretation of the seismic stratigraphy in the context of the drilling results and subsequent, more detailed studies. Only that part of the sequence related to changes in climate and deep circulation is discussed (see Srivastava, Arthur, et al., 1987; Site 645 chapter for details).

\section{Seismic Sequence 2: Upper Pliocene-Pleistocene}

Seismic sequence 1 is $0.4 \mathrm{~s}$ thick near Site 645 from the seafloor to the top of what has been defined as reflector R1 (Fig. 19). The base of seismic sequence 1 at Site 645 occurs at 388 mbsf (calculated using an interval velocity of $1850 \mathrm{~m} / \mathrm{s}$ ). Synthetic seismograms (Srivastava, Arthur, et al., 1987) suggest that an impedance discontinuity lies near 370 mbsf. Seismic sequence 1 corresponds to lithologic Units I and II, except that the lower boundary of lithologic Unit II occurs about $50 \mathrm{~m}$ above the depth calculated to the reflector R1 (Fig. 19).
We subdivided seismic sequence 1 into three subunits on the basis of internal reflection characteristics. Seismic sequence 1A extends from the seafloor to a depth of $0.18 \mathrm{~s}$ at Site $645(0-166$ mbsf) and is transparent to slightly reflective in the multichannel profile, but exhibits numerous horizontal reflections in the single-channel lines. These characteristics are maintained over much of the region (Fig. 18), and there is little variation in thickness of seismic sequence $1 \mathrm{~A}$. Seismic sequence $1 \mathrm{~A}$ corresponds to lithologic Unit I, which consists of rhythmically interbedded calcareous muddy sand and silty mud in the uppermost 72 mbsf (lithologic Subunit IA) and interbedded calcareous silty clay and silty mud from 72 to 168 mbsf (Subunit IB). Dropstones and other sedimentary characteristics indicate a primarily ice-rafted origin for the sequence. The transparent nature of seismic sequence $\mathrm{IA}$ and its rather uniform drape over topography in the region (Fig. 20) agrees with the evidence from the cores that these sediments were deposited mainly by ice rafting.

We interpret the strata of lithologic Unit I as having been deposited mainly by melting ice and as having had some contribution by downslope redeposition of various sorts. Bottom currents played a minor role in deposition or winnowing of the sediment. The seismic character of Unit I supports this interpretation in that the deposits are of uniform thickness over much of the region, including the Baffin Island lower slope, and the interval is somewhat uniform and seismically transparent. However, a high-resolution, single-channel seismic record across Site 645 illustrates that downslope redeposition was important near the site. At least one thick (40-70 mbsf), chaotic mass, interpreted as being a slump deposit, reached the site during Unit I deposition (Srivastava, Arthur, et al., 1987). Other such slump intervals are also visible. On the eastern side of the basin, seismic sequence $1 \mathrm{~A}$ thickens to $>0.4 \mathrm{~s}$ (Figs. 20B, 20C), where multiple, fairly high-amplitude reflectors occur and appear to interfinger with or fade into the transparent unit toward the west. These reflectors probably represent deposits of multiple episodes of turbidite sedimentation from the edge of the West Greenland shelf. The age of lithologic Unit I (seismic sequence 1A) is early Pleistocene to Holocene.

Seismic sequence 1B occurs at Site 645 from 0.18 to $0.42 \mathrm{~s}$ sub-bottom (Fig. 19), with a top of $167 \mathrm{mbsf}$ and a base of about 388 mbsf at the site. Internal reflections are chaotic, characterized by multiple diffractions. Seismic sequence $1 \mathrm{~B}$ pinches out to the west on the flanks of the pronounced basement high and passes into an interval of more pronounced horizontal reflectors east of the site (Fig. 20). Seismic sequence 1B is thickest toward the deepest point in the basin, reaching about $0.4 \mathrm{~s} \mathrm{(260}$ m) thick. In our cores from Site 645 , seismic sequence 1B corresponds closely to lithologic Unit II, which extends from 168.1 to 335 mbsf. These sediments are primarily interbedded, noncalcareous silty mud, clayey silt, and silty clay; dropstones are distributed throughout. The chaotic nature of the internal reflections within Subunit lB is perhaps caused by one or more layers of coarse ice-rafted debris. A 5-m-thick, fine-grained sand occurs at about 275 mbsf (Fig. 19). The base of lithologic Unit II probably corresponds to reflector $\mathrm{ROh}$, for which we calculated a depth of 333 mbsf. We failed to recover sediment from this interval in three separate attempts to core.

Geophysical logs give no indication that unconsolidated sand exists at 333 mbsf (see Srivastava, Arthur, et al., 1987; Site 645 chapter). In fact, the interval is characterized by higher density similar to that of ice-rafted, gravelly mud intervals higher in the hole. Lithologic Unit II is primarily composed of ice-rafted material and perhaps some finer-grained material derived from the east by dilute-suspension turbidity currents (Hiscott et al., this volume). Relatively strong, deep currents were present during deposition of seismic sequence 1 , as illustrated by the depositional features upslope from Site 645 in about 900 to $1000 \mathrm{~m}$ of water (Fig. 20). These upslope, migrating, large, dunelike fea- 


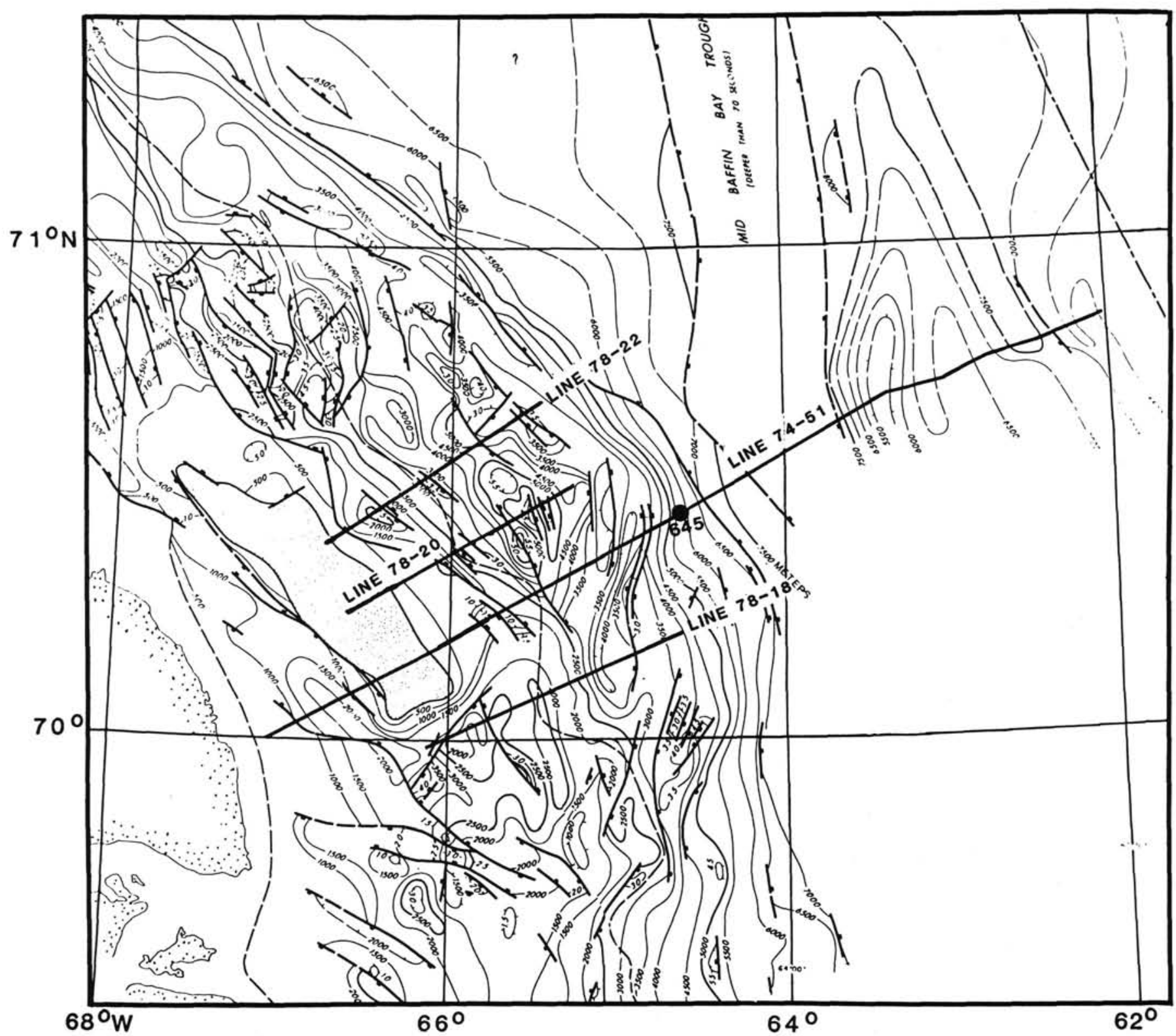

Figure 18. Index map showing location of Site 645 in southwestern Baffin Bay and tracks of multichannel seismic lines referred to in text and shown in Figures 20 and 21. Contours are depth to basement in meters, calculated on the basis of seismic network.

tures are typical of current-deposited depositional ridges (Fig. 21) associated with deep contour currents. Seismic records suggest gradual shoaling of the focus of these currents through the Pliocene-Pleistocene.

Seismic sequence $1 \mathrm{C}$ is not well represented at Site 645 in the seismic records, except as a thin horizon above $\mathrm{R} 1$, and it is essentially absent from the region west of the site. This sequence thickens substantially toward the West Greenland margin, where it is as much as $1 \mathrm{~s}$ thick (perhaps $900 \mathrm{~m}$ ). A number of weak-tostrong parallel reflectors characterize the subunit. Most of these reflectors terminate against R1 progressively westward (Fig. 20). As much as $50 \mathrm{~m}$ of muddy sand and silt occurs in the interval between 300 and $388 \mathrm{mbsf}$ in Site 645 , primarily above what we have picked as the $\mathrm{R} 1$ reflector. These interbedded, muddy sands and silts may represent the later stages of progradation of sediment derived from West Greenland over the R1 surface.

\section{Seismic Sequence 2: Middle Miocene-Upper Pliocene}

Seismic sequence 2 constitutes many flat-lying reflectors below R1 that onlap reflector R2 at the top of the underlying seismic sequence 3. Examination of multichannel line 74-51 (Fig. 20) and other seismic lines across Baffin Bay indicates that seismic sequence 2 is relatively constant in thickness, except in those places where the top of the unit is eroded and where underlying reflectors crop out at the R1 surface. At Site 645 and to the west of the basement high, which lies landward of the site, seismic sequence 2 thickens to perhaps $0.6 \mathrm{~s}(>600 \mathrm{~m})$. At the site it is about $0.5 \mathrm{~s}(525 \mathrm{~m})$ thick, but has a maximum thickness of about $0.65 \mathrm{~s}(790 \mathrm{~m})$ to the east. The base of this sequence is a prominent unconformity, which is marked by the strong reflector (R2) at the top of seismic sequence 3 at about 913 mbsf at Site 645. Seismic sequence 2 corresponds to lithologic Sub- 


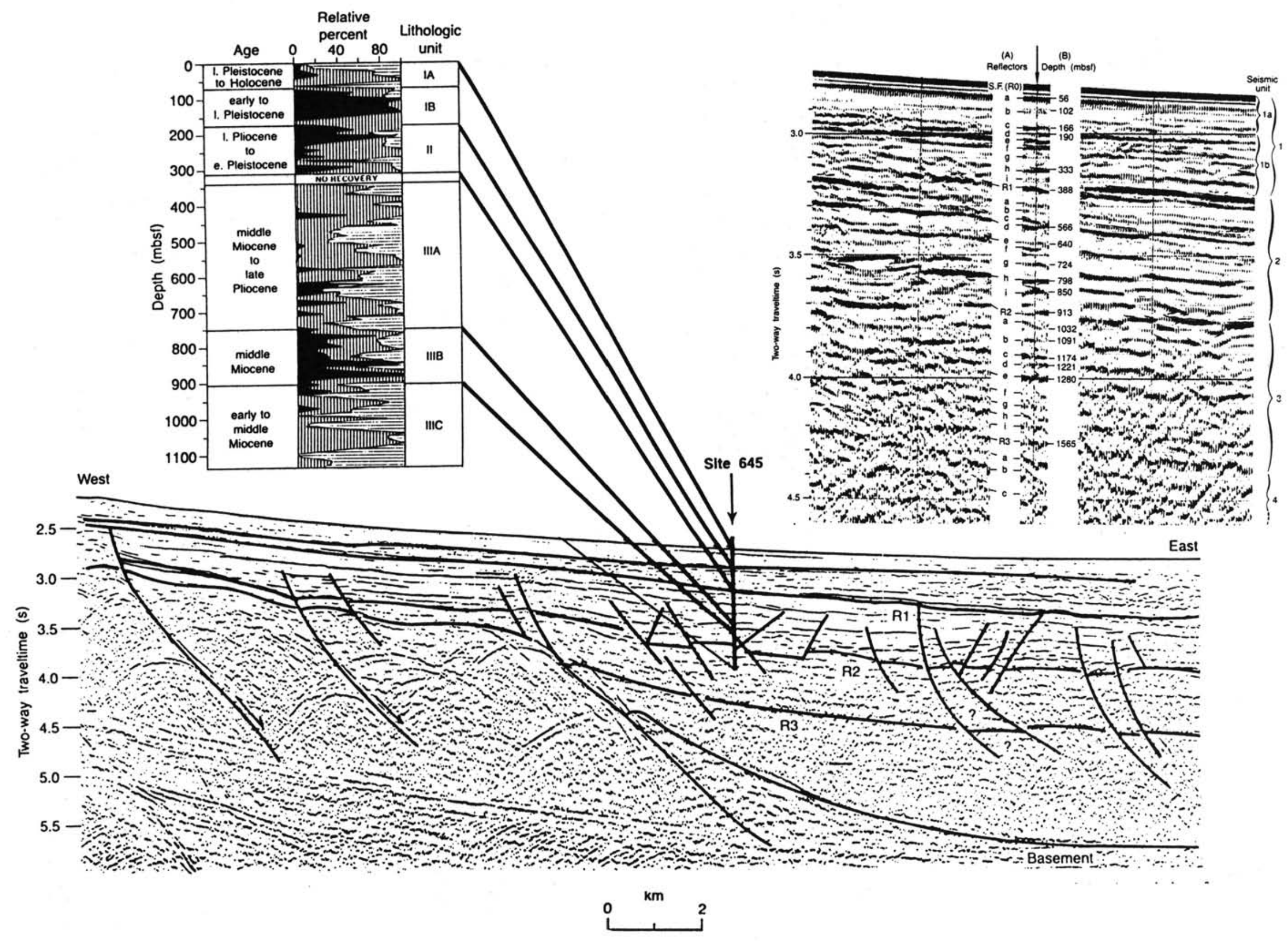



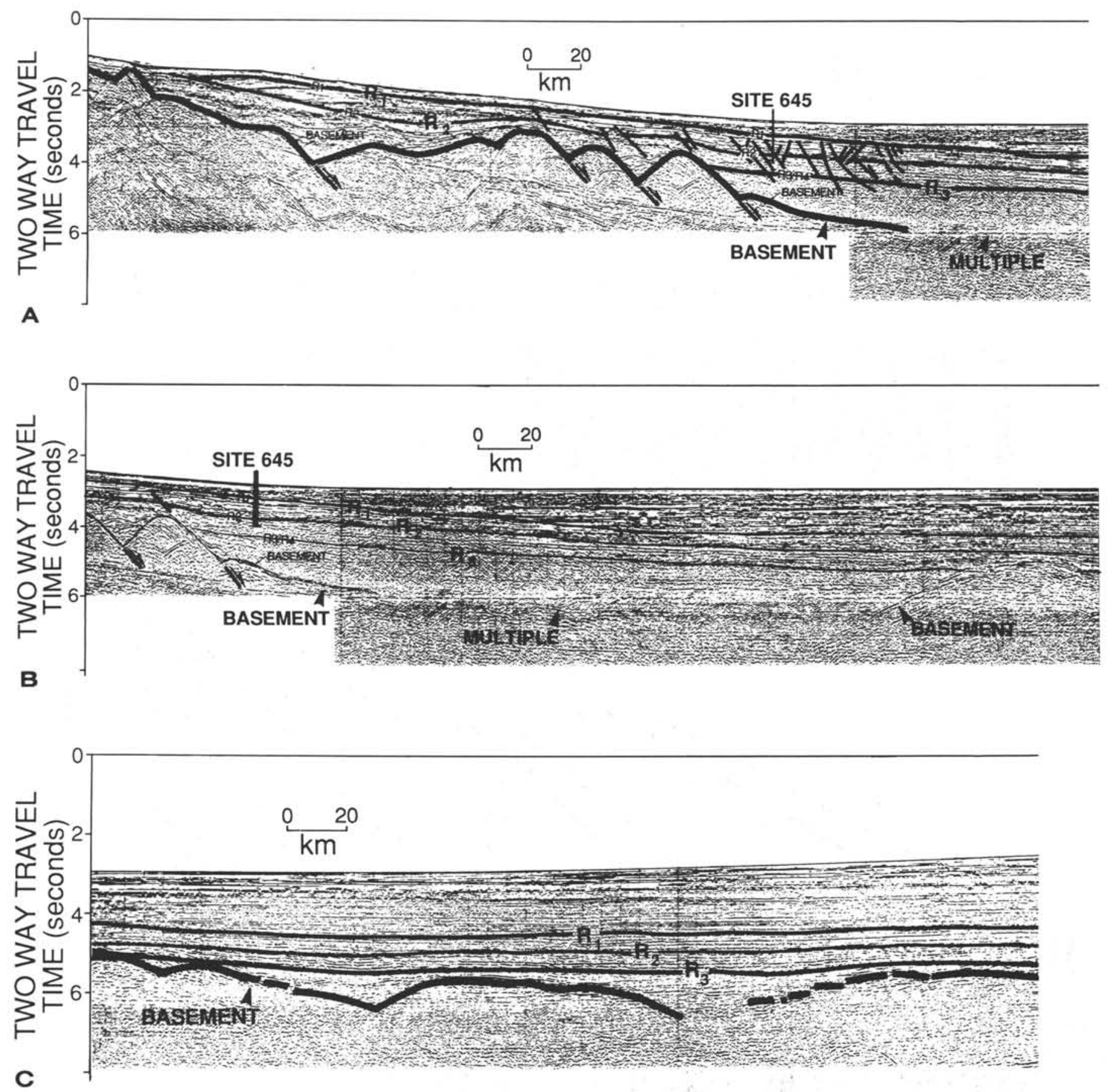

Figure 20. Entire length of multichannel seismic line 74-51 in Baffin Bay. A. Westernmost segment. B. Central segment. C. Easternmost segment that passes over the central basin trough.

units IIIA and IIIB. Our pick for the depth of reflector R2 corresponds closely to the lower boundary of lithologic Subunit IIIB.

The strata of Subunits IIIA and IIIB are predominantly muddy sandstones and siltstones with interbedded silty and sandy mudstone. Subunit IIIA contains some graded sandstone beds, but most beds are bioturbated to homogeneous or somewhat laminated. Variations in the proportions of sandstone and siltstone beds occur downcore, apparently leading to impedance contrasts that cause several strong-to-weak, continuous-to-discontinuous reflectors within seismic sequence 2 .
Seismic sequence 2 does not thicken toward the east (West Greenland), suggesting that the strong progradation and high sediment supply that characterized deposition of seismic sequence 1 were not present during the middle Miocene through early Pliocene. In fact, the uniformity in thickness of seismic sequence 2 onlaps onto reflector R2 toward the west, and the sedimentary textures and structures in lithologic Subunits IIIA and IIIB suggest that deposition of seismic sequence 2 was largely controlled by bottom currents. On the basis of textural studies, Cremer (this volume) has suggested that contourite depositional processes dominated during Subunit IIIA deposition (730-600 


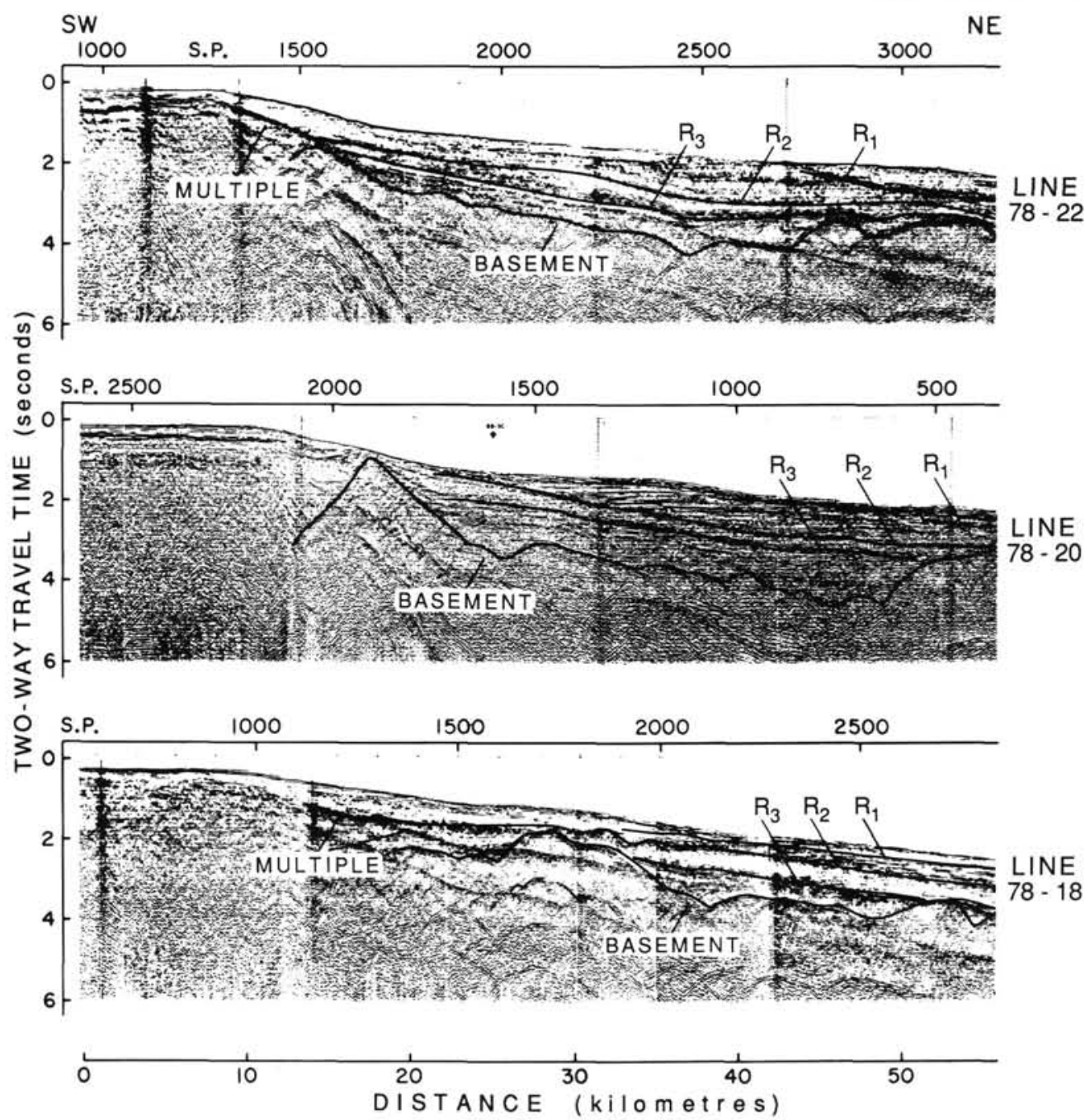

Figure 21. Multichannel lines 78-22, 20, and 18 from north to south along the Baffin Island margin (see Fig. 18 for locations). Note features above reflector R2 that resemble sediment drifts in morphology and internal reflection characteristics.

mbsf), but that bottom currents were probably weakest during Subunit IIIB deposition. In the western part of the basin, deposition was profoundly affected by bottom currents, as indicated by the presence of large migrating depositional ridges (Fig. 21). However, some evidence of sediment redeposition by turbidity currents exists at Site 645 in lithologic Subunits IIIA and IIIB (e.g., Hiscott et al., this volume), probably derived from the Baffin margin. In addition, some of the coarse, sand-size to granular particles and isolated pebbles may indicate an icerafted source (Korstgard and Nielsen, this volume).

The onset of major glacial ice rafting in Baffin Bay, recorded by the first abundant dropstones and other coarse sediment, was at least as early as $2.5 \mathrm{Ma}$ (base of Unit II at $335 \mathrm{mbsf}$ ) or perhaps as early as about $3.5 \mathrm{Ma}(465 \mathrm{mbsf})$. The beginning of major glacial activity in this region, therefore, could have preceded ice rafting in the northern North Atlantic by at least 1 m.y., on the basis of a 2.3 to 2.4 Ma date obtained as the result of drilling during DSDP Legs 81 (Roberts, Schnitker, et al., 1984) and 94 (Shackleton et al., 1986) and 2.5 Ma at Sites 646 and 647 (Srivastava, Arthur, et al., 1987). However, isolated pebbles and granules in strata as old as late Miocene (605 mbsf) at Site 645 could indicate the presence of at least seasonal sea ice in Baffin Bay as early as $8.5 \mathrm{Ma}$. Pebbles are common in strata above $460 \mathrm{mbsf}$, but strata consist predominantly of sedi- mentary clasts (especially black shale) below 320 mbsf (e.g., Korstgard and Nielsen, this volume). Clark (1982) argued for a beginning of glaciation in the Arctic region at 5 to $6 \mathrm{Ma}$ (Aksu and Mudie [1985] suggested $4 \mathrm{Ma}$ ), and Eldholm, Thiede, et al. (1987) suggested an age of $4.3 \mathrm{Ma}$ for the beginning of the glacial regime in the Norwegian-Greenland Sea. This later age is based primarily on an increase in the terrigenous component in sediments at Site 642. An earlier age for continental glaciation in the Baffin Bay region is not unreasonable, considering its high continentality and the lack of influence by advection of warm-water masses, in contrast to those associated with the Gulf Stream in the North Atlantic and Norwegian-Greenland Sea area.

\section{DEEP-WATER CIRCULATION HISTORY}

\section{Paleogene}

Previous studies have shown that sediment drift formation apparently took place near the Eocene/Oligocene boundary in the eastern North Atlantic (e.g., Kidd and Hill, 1986a, 1986b; Masson and Kidd, 1986) and that a major erosional unconformity ( $\mathrm{Au}$ ) was formed at about the same time in the northern North Atlantic during the early Eocene through earliest Oligocene. The seafloor at Sites 647 and 112 should have been bathed 
by the same deep watermasses as sites on the Hatton-Rockall Plateau flanks (e.g., Site 552), as well as having been characterized by similar productivity and sea-surface temperatures in the Eocene. By the latest Eocene (Chron 13, Fig. 22D) the pattern of seafloor spreading probably had created several isolated elongate basins that could have been characterized by different deep-water structure. The major question is whether the deepwater masses in this region were of proto-"AABW" or proto"NADW" character, or neither. Various scientists have suggested that exchange across the present Wyville-Thomson Ridge (Fig. 22D) permitted the first cool, dense Norwegian-Greenland Sea overflow to the deep, eastern North Atlantic near the time of the Eocene/Oligocene boundary (e.g., Miller and Tucholke, 1983; Roberts, Schnitker, et al., 1984). Erosional events and hiatuses, attributed to this overflow, characterize the Eocene/Oligocene at a number of eastern North Atlantic DSDP Sites (Roberts, Schnitker, et al., 1984), and a major seismic reflector of late Eocene/Oligocene age apparently marks the base of sediment drifts there. This is reflector "R4" of Miller and Tucholke (1983), equivalent to the "Brown" of Masson and Kidd (1986). Note that "R4," as originally defined by Roberts (1975) and discussed further in Roberts et al. (1981) for this region, is now "R2" of Miller and Tucholke (1983) and "Green" of Masson and Kidd (1986). The latter reflector (R2) has been designated as latest early Miocene in age and is a mid-drift reflector (Masson and Kidd, 1986). There is, therefore, a suggestion of active geostrophic currents and possible construction of drifts as early as the late Eocene in the eastern North Atlantic. However, it is unclear whether northern-source bottom water could have been a major influence in the Labrador Sea until much later, unless derived from an Arctic source through Baffin Bay and across the Davis Strait. Otherwise, the Labrador Sea was tectonically isolated from the eastern North Atlantic by a number of topographic features, although leakage of deep waters might have occurred through the inferred Charlie Gibbs Fracture Zone ("CG" in Fig. 22D), as it does today (Garner, 1972; Harvey, 1980; Shor et al., 1980).

It is more likely that a proto-"AABW" occupied the Labrador Sea until some time in the Oligocene or later, when subsidence of the Reykjanes Ridge and others allowed deep-water communication with the eastern North Atlantic, or until the Greenland-Iceland Ridge was breached (e.g., Vogt, 1972) and NSOW-type water flowed directly into the Labrador Sea. The isolation of the Labrador Sea at this time, except from a direct southern source, might explain the lack of evidence for an erosional episode and/or formation of sediment drifts in the Eocene/Oligocene there. The interval between R2 and R3 in the seismic records is of variable thickness over the region and is generally thickest along the axes of the sediment ridges built by bottom-current deposition. There are no features that suggest deposition by currents within the sediments bounded by R2 and R3 at either Site 647 or DSDP Site 112 (Srivastava, Arthur, et al., 1987), and no equivocal features appear in seismic lines across the sites themselves that might suggest current activity. Nonetheless, small depositional ridges probably formed above R3 (Figs. 15 and 23). At DSDP Site 112, either R3 represents an unconformity between the middle Miocene and upper Oligocene strata at about 220 mbsf $(0.24 \mathrm{~s}$; Fig. 23$)$-therefore, what we identified as the R3 surface there is somewhat younger than at Site 647 -or R3 perhaps represents the same change from biogenic carbonate to opal-rich sediment in the lower Oligocene. In the latter possibility, however, the depth of R3 at Site 112 (about 315 mbsf) should be significantly greater than calculated using a reasonable range of seismic velocities (i.e., the reflector should occur at a depth between 240 and $270 \mathrm{mbsf}$ ). Therefore, the R3 reflector at Site 647 may not correlate with that at Site 112. Nevertheless, drift deposition occurred above R3 over the region; therefore, mainly after the middle Oligocene.
Because drilling at Site 646 did not penetrate deeply enough, there is no definitive way to identify a reflector in the northern Labrador Sea equivalent to R4 elsewhere in the eastern North Atlantic (Miller and Tucholke, 1983) that might represent a period of intensified erosion of the seafloor during the late Eocene and early Oligocene. Reflector R3/R4 in the Eirik Ridge region is of late Miocene age and perhaps corresponds to a brief hiatus or change in sedimentation rate overlain by sediment of $7.4 \mathrm{Ma}$ age at Site 646. Strata below R3/R4 cored in Site 646 are also of late Miocene age (oldest is ca. $8.6 \mathrm{Ma}$ ); therefore, much of the upper part of seismic sequence 4 below the R3/R4 reflector may also be Miocene in age. Evidence of one older erosional episode exists within seismic sequence 4 on Eirik Ridge and may be of late-middle Miocene age (Fig. 7). The average rates of sedimentation below the upper part of seismic sequence 4 must be slower than those in the upper Miocene to Holocene interval above, assuming that the site lies over crust of Chron 24 age.

Deposition of seismic sequence 4 (below R3/R4) filled in troughs and progressively onlapped and draped the basement during the middle Eocene to early late Miocene (52-7.5 Ma). This assumes that the region was not uncommonly uplifted during reorientation of the ridge axis during Chron C24 (see Srivastava and Arthur, this volume) and was accessible to sedimentation. The seismic record shows no major variations in thickness between any two reflectors in seismic sequence 4 except in the upper part of this sequence on the outer (southward-facing) portion of Eirik Ridge (Fig. 7C). We have no age control for this latter event. It may correspond to a late middle Miocene erosional episode noted elsewhere (see below) but did not involve construction of current-influenced sedimentary bodies. Chaotic, diffracted reflections are found within seismic sequence 4 under Eirik Ridge below R3/R4 (Fig. 7) and above a deeper reflector that may correlate with R4 in the eastern Atlantic (Miller and Tucholke, 1983). These reflections are similar to those found by Mountain and Tucholke (1985) between reflector Merlin (dated at 11 to $12 \mathrm{Ma}$ ) and $\mathrm{Au}$ (intra-Oligocene), inferred to represent current-influenced deposition.

\section{Neogene}

This event in the Labrador Sea suggests that intensified bottom currents may have caused major erosion and sediment redistribution in the late middle Miocene. The timing of this event is difficult to pin down on Eirik Ridge and along the west Greenland margin, but there is a pronounced unconformity in seismic records that appears about 0.1 to $0.3 \mathrm{~s}$ below the R3/R4 reflector (late Miocene; 7.5 Ma), on the outer part of Eirik Ridge (Fig. 6) that we have correlated from Site 646 through a series of multichannel seismic lines (Fig. 5) to the West Greenland margin. This erosional event mainly affects the lower slope region. Although there is no direct age control, we suggest that this event occurred in the late middle Miocene (12 to $10 \mathrm{Ma}$ ), which is the age that we derive from extrapolation of sedimentation rates at the base of Site 646. In addition, there is a pronounced hiatus at Site 647 that encompasses this time (17.5 to $\sim 5.6 \mathrm{Ma}$ ) and corresponds to reflector R2 on Gloria Drift. This reflector probably corresponds to reflector "U" of Hinz et al. (1979), who believed that it represented an unconformity surface of late Miocene age. The reflector below R3/R4 also may be equivalent to reflector Merlin (ca. 10 to $12 \mathrm{Ma}$ ) in the western North Atlantic region (e.g., Mountain and Tucholke, 1985; Tucholke and Mountain, 1986), which may mark the base of stable sediment drift formation there. The stabilization of drift deposits in the western North Atlantic that began about $10 \mathrm{Ma}$ may correspond to increased sediment influx and/or more stable, high-velocity bottom currents (e.g., McCave and Tucholke, 1986); Miller et al. (1987) also called upon a glacial event, lowering of eustatic sea level, and a canyon-cutting event (M1) along the eastern North American margin at that time, all of 

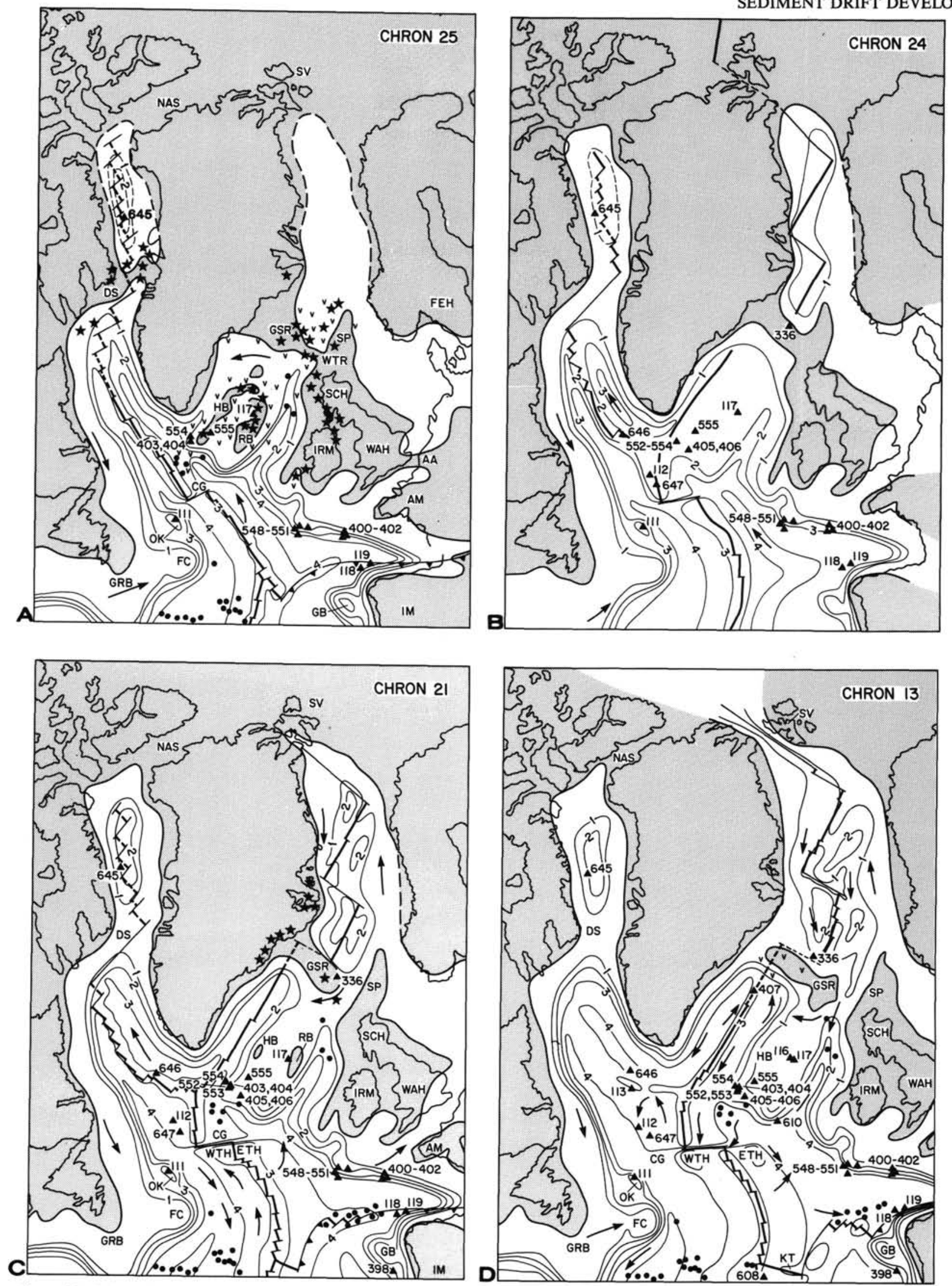

Figure 22. Series of reconstructions of the Labrador Sea-Norwegian Sea-North Atlantic region (adapted from Tucholke and Mountain, 1986). A. Chron 25-earliest Eocene. B. Chron 24-early Eocene. C. Chron 21-middle to late Eocene. D. Chron 13-latest Eocene. Numbers by solid triangles = DSDP-ODP sites. Stars = volcanic (basalt) outcrops. Dots = seamounts. Inferred land area is stippled. Arrows indicate inferred surface and deep currents (McCave and Tucholke, 1986). 


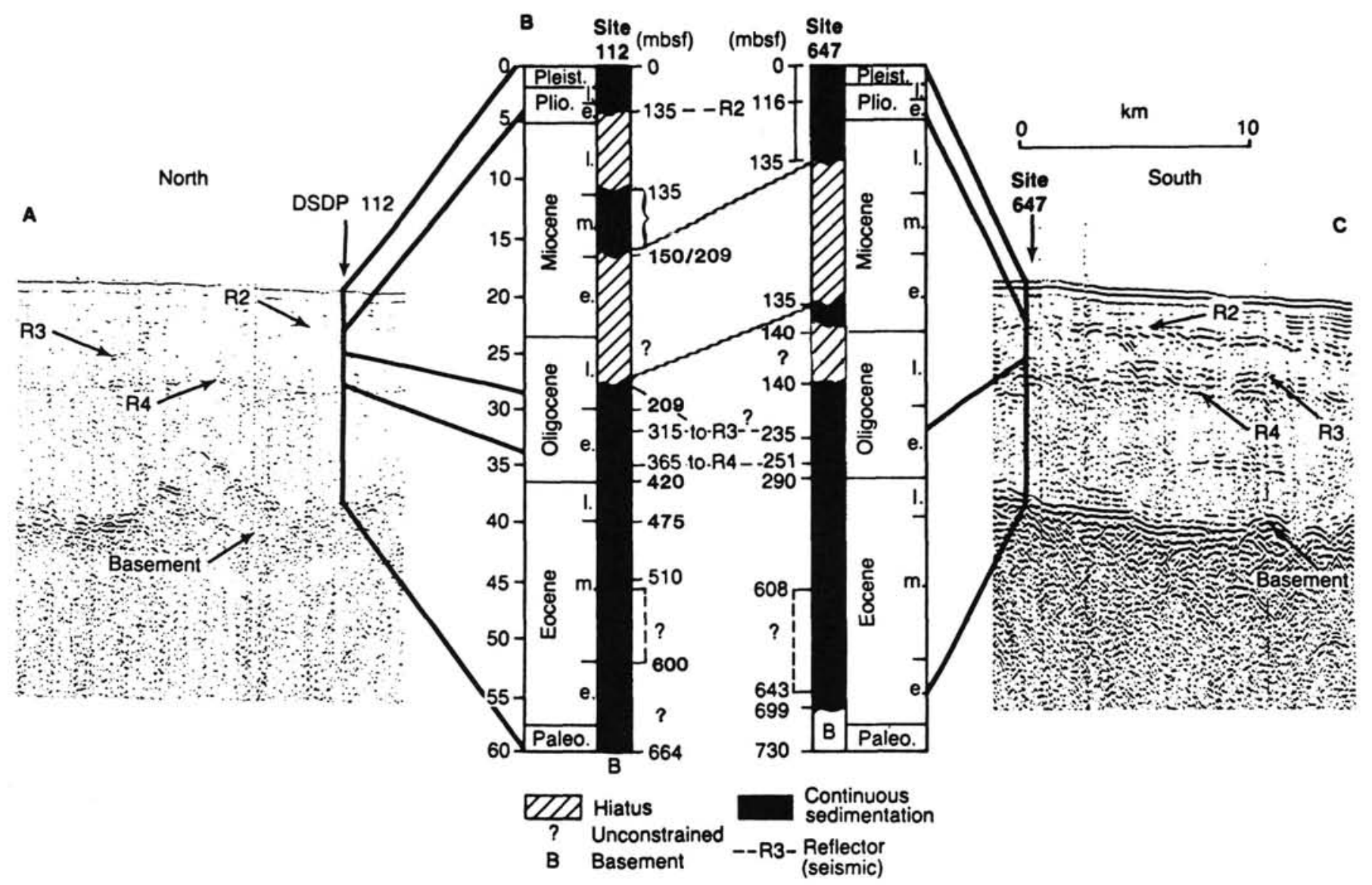

Figure 23. Comparison of hiatuses and depths to distinctive lithologic features and their seismic equivalent at DSDP Site 112 and ODP Site 647.

which should have led to increased sediment supply. Merlin and the Labrador Sea erosion event, R3' may correspond to a reflector of global importance as well; Mayer et al. (1986) suggested that their reflector IM-P (10 Ma; NH4) in the Pacific marked an important global paleoceanographic event, including major cooling and reorganization of bottom-water masses in the North Atlantic. There is also a reflector of that approximate age in eastern North Atlantic drift sequences (R1 of Kidd and Hill, 1986a). The Labrador Sea event is approximately the same age as the major cooling event and advent of significant surface to bottom mixing in the Norwegian-Greenland Sea (13.5 to 12.3 Ma; Thiede, Eldholm, et al., 1987) which has been interpreted from the record at Site 642 .

There is also evidence of contour-current activity in western Baffin Bay in the middle Miocene (see above) that gradually waned and shoaled along the margin. Features on seismic lines along the Baffin Island margin at water depths between 1200 and $800 \mathrm{~m}$ strongly resemble bottom-current-deposited sediment drifts, which we interpret as the product of strong southwardflowing contour currents. Correlation of the major seismic reflectors with strata recovered at Site 645 indicates that the main current-influenced sedimentary bodies are probably middle Miocene through early Pleistocene in age. The currents at lower slope depths may not have been as active during much of the late Pleistocene, because lithologic Unit I (seismic sequence 1) drapes the drift structures.

The unexpectedly pronounced but variable influence of deep currents during deposition of lithologic Unit III (early Miocene to late Pliocene) in western Baffin Bay and the rare occurrence of planktonic biota and decreased marine productivity (Stein et al., this volume), above about 720 mbsf, indicate the incursion of warmer North Atlantic waters into the basin, and suggest possible southward-directed flow of Arctic watermasses to the Labrador Sea that began during the middle Miocene. Some dinocysts with subarctic or North Atlantic affinities occur in sediment of middle to late Miocene age (lithologic Unit IIIB) and indicate that cool-temperature conditions existed in part of the bay at that time and probably reflect periodic incursions of North Atlantic waters (e.g., de Vernal et al., this volume). Calcareous microfossils and dinocysts having North Atlantic warm-temperate affinities occur in some intervals of the lower Miocene at Site 645, possibly indicating the waning influence of relatively warmer northward flow from the North Atlantic to Baffin Bay at that time. Evidence of development of the cold Labrador Current running over the Labrador shelf is found in sediments as old as the Miocene and certainly the early Pliocene (Gradstein and Srivastava, 1980). Such evidence indicates that cooling at high latitudes led to the increasing influence of Arctic water-masses that penetrated into the North Atlantic as surface currents and possibly even as deep water-masses. Overflow from Baffin Bay across the Davis Strait during the middle Miocene to Pliocene possibly contributed to the increased volume and advection of NADW-type water formed at that time.

Reflector R2 is an erosional unconformity over at least part of the region, particularly on the Baffin Island shelf and slope, where it cuts deeply into strata of probable Paleocene to early Miocene age. Middle Miocene, partly bottom-current-deposited strata (Cremer, this volume) of lithologic Subunit IIIB overlie $\mathrm{R} 2$, suggesting that this reflector and unconformity marks the onset of vigorous southward-directed circulation in the basin. The onset of this circulation was coincident with evidence of cooling and/or more restricted environmental conditions from 


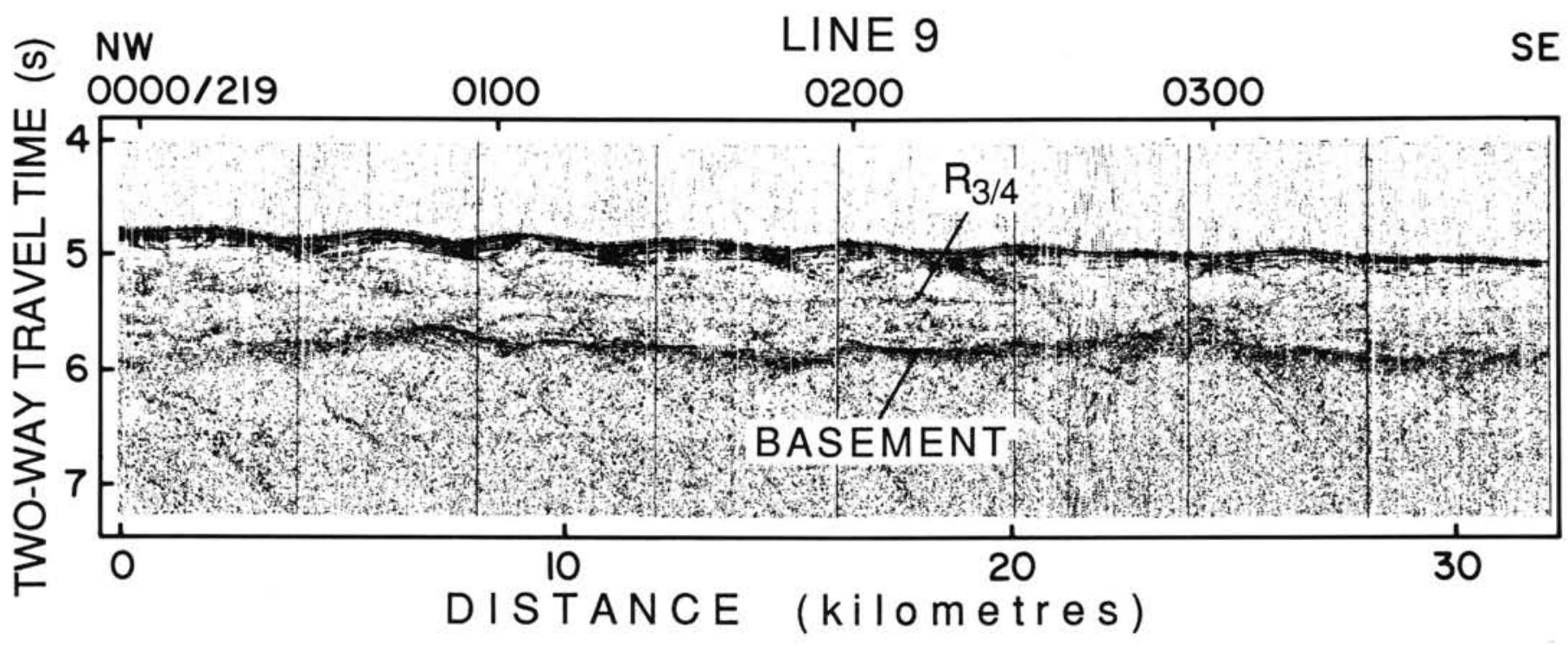

Figure 24. Line 9 across the central part of Gloria Drift showing sediment waves that appear to be developed above the R3/4 horizon.

faunal and floral assemblages after about $14 \mathrm{Ma}$ and may be close in timing to significant cooling and convection in the Norwegian Sea (Thiede, Eldholm, et al., 1987). Redeposition and reworking of benthic foraminiferal faunas from shallower depths and strata from Paleogene to Miocene age in parts of lithologic Unit III (Srivastava, Arthur, et al., 1987) are consistent with erosion and transport of detritus to the site by both bottom and some turbidity currents. Bottom-current activity may have begun somewhat earlier in deeper water at Site 645 during deposition of lithologic Subunit IIIC (Cremer, this volume; Hall and King, this volume) in the mid-Miocene.

At Site 646 on Eirik Ridge, the next youngest significant seismic reflector and sedimentation event occurs at R3. This reflector was dated at about 7.5 Ma (late Miocene) and corresponds to a change in sedimentation rate (Fig. 27), benthic foraminiferal fauna (Kaminski et al., this volume) and in texture. There is also some evidence of erosion on this surface in seismic lines (see above), but it is not as major an erosional event as R3' below it. On Gloria Drift, an overall condensed zone at Site 647 corresponds to this event. Again, there is some evidence that this Labrador Sea event is manifested on a global basis. Mayer et al. (1986) identify a regionally important reflector in the central Pacific (IM-B) that is about 6.7 to $7.0 \mathrm{Ma}(\mathrm{NH} 7)$ in age and corresponds to a cooling, glaciation, and sea level event. However, there is no equivalent major reflector identified in either the western or eastern North Atlantic (Fig. 26). Below Reflector $\mathrm{R} 3$, the benthic foraminiferal assemblage is dominated by Nuttalides umbonifera (Kaminski et al., this volume), which is considered an indicator of corrosive bottom water. This $N$. umbonifera Assemblage is similar to the upper Miocene deep-water assemblages encountered at other abyssal sites in the North Atlantic (e.g., Berggren and Schnitker, 1983; Murray, 1984; Schnitker, 1986). Today, N. umbonifera-dominated assemblages are found in areas of the Atlantic underlain by AABW; therefore, we may assume that late Miocene bottom water in the Irminger Basin may have had some southern component. Accompanying $N$. umbonifera are agglutinated benthic taxa having smooth, fine-grained tests. In the modern ocean, agglutinated assemblages, which contain a large proportion of these forms, typify environments that are relatively tranquil and undisturbed by strong bottom currents. Above reflector R3, the benthic forami- niferal assemblage abruptly changes to one dominated by coarse agglutinated taxa accompanied by calcareous benthic forms (without meaningful numbers of $N$. umbonifera) that are more typical of modern NADW. The only other place in the North Atlantic region where assemblages dominated by coarse agglutinated forms in Miocene age sediments have been observed is in the Norwegian-Greenland Sea. These coarse agglutinated assemblages are found in environments that are disturbed by abyssal currents, such as beneath the modern Western Boundary Undercurrent. We interpret the 7.5-Ma benthic faunal change at Site 646 as indicating the onset of significant amounts of Denmark Straits overflow water (DSOW) during the late Miocene. Significantly, the benthic faunal change is preceded by an abrupt change in the coiling ratio of the planktonic foraminiferal species Neogloboquadrina atlantica (Berggren) from right-coiling (below) to left-coiling (above) at approximately $8.6 \mathrm{Ma}$ (Aksu and Kaminski, this volume). In the modern ocean, left-coiling populations of Neogloboquadrina are typical of polar and subpolar environments. The change in coiling ratios coincides with a permanent $1.5 \%$ shift in surface-water $\delta^{18} \mathrm{O}$ values (Aksu and Hillaire-Marcel, this volume), which may be interpreted as indicating a $6^{\circ} \mathrm{C}$ cooling of surface waters in the East Greenland Current.

Deposition of seismic sequence 3, all of which was cored at Site 646 , occurred during the upper part of the late Miocene and earliest Pliocene (7.4-4.5 Ma). The base of seismic sequence 3 is conformable to disconformable, with underlying seismic sequence 4 . This suggests a hiatus or variation in sedimentation rate at the R3/R4 reflector over the region. The hiatus could have been caused by strong erosive currents.

The preservation and abundance of faunal and floral assemblages below about $680 \mathrm{mbsf}$ (R3/R4 reflector) differ from those above. Carbonate contents are $<5 \%$, and preservation of calcareous plankton is relatively poor. The low abundance of calcareous-dominated benthic foraminiferal fauna is significantly different from the agglutinated benthic foraminifer-dominated fauna above 670 mbsf.

This evidence suggests that the "modern" pattern (Murray, 1984; Schnitker, 1986) of deep circulation in this part of the North Atlantic was established (some time in the late Miocene about 8.2-7.5 Ma) when significant cooling of surface water oc- 

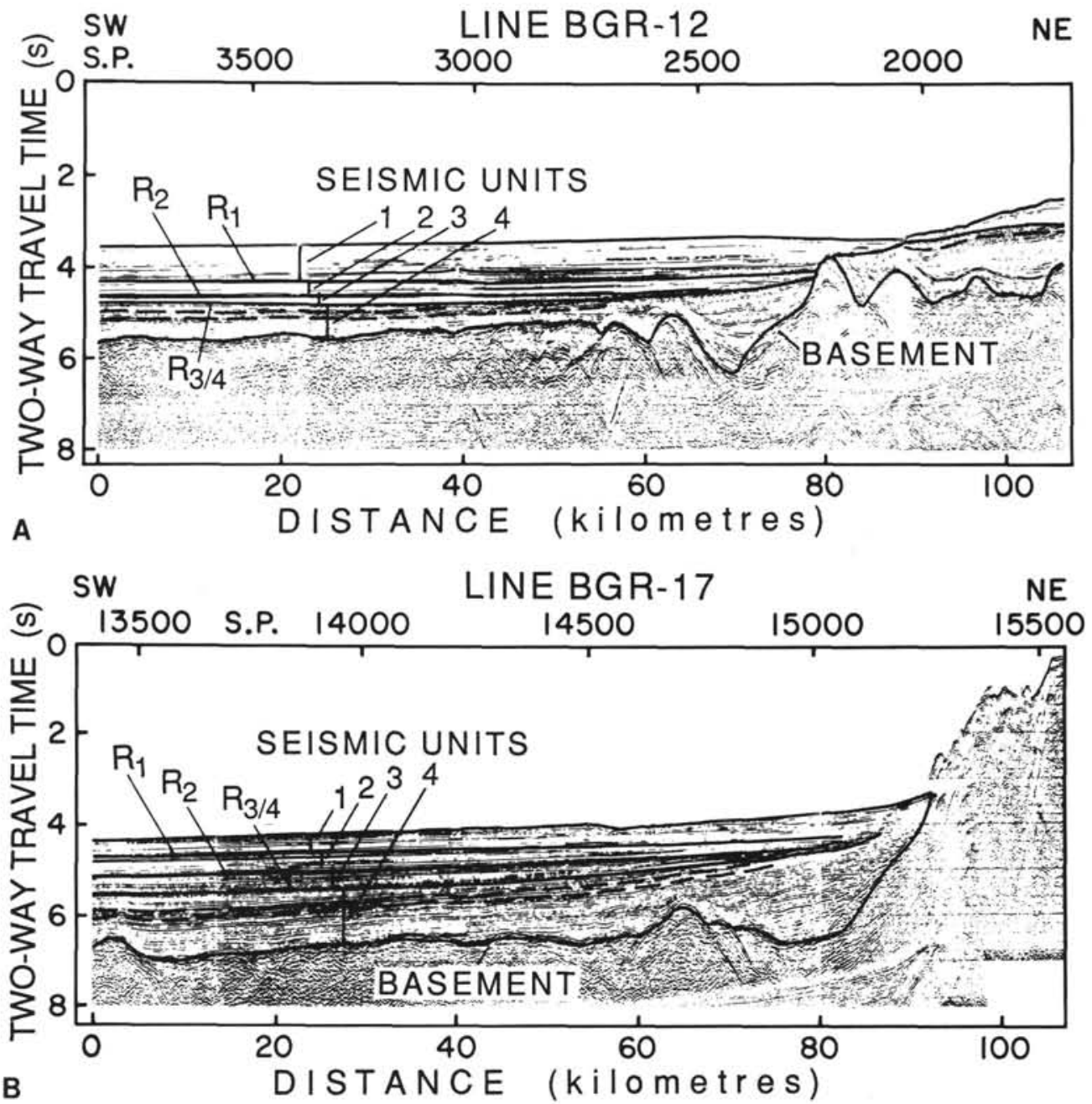

B

W

LINE BGR-3

$E$

ฮ

S.P.

3000 2500

2000

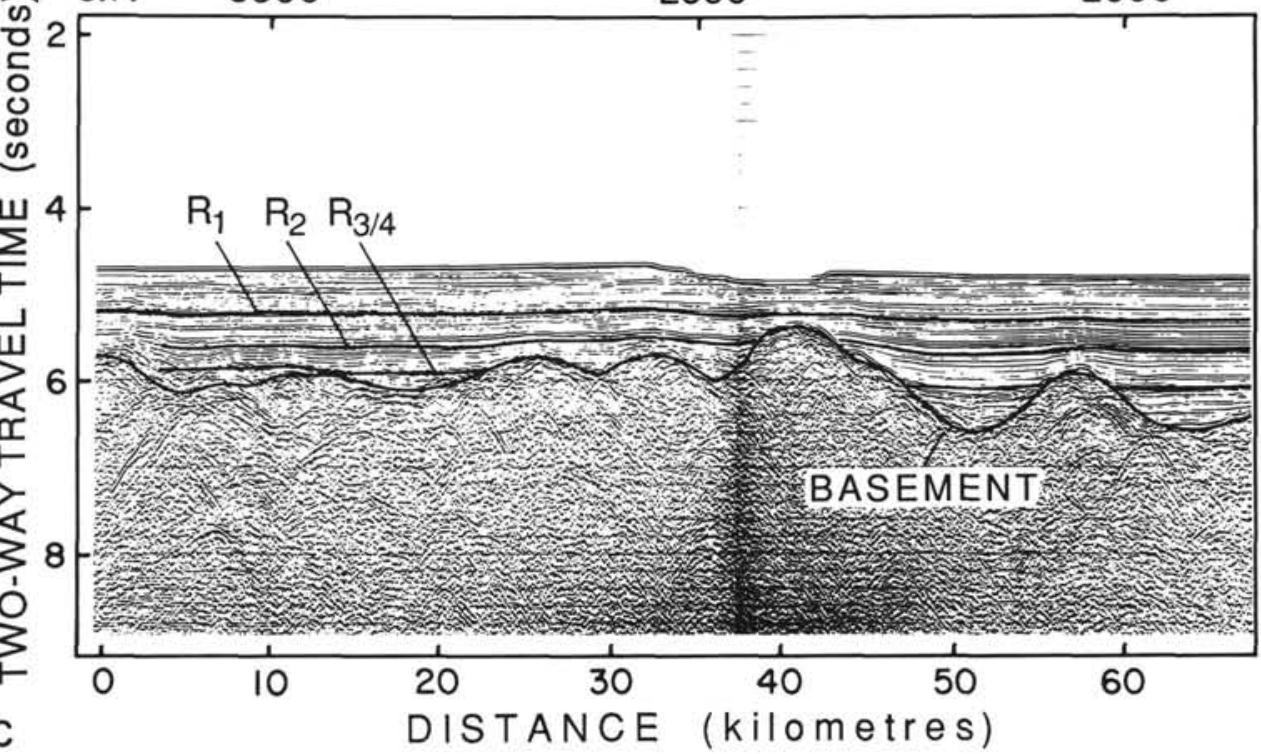

Figure 25. Segments of multichannel lines BGR-12 (A), BGR-17 (B), and BGR-3 (C) from north to south along the West Greenland margin. Note that R3/4 reflectors appear to mark an erosional unconformity of middle-late Miocene age and that stratified NAMOC deposits may be older (upper Miocene?) in this part of the Labrador Sea than farther to the south, near Gloria Drift. 


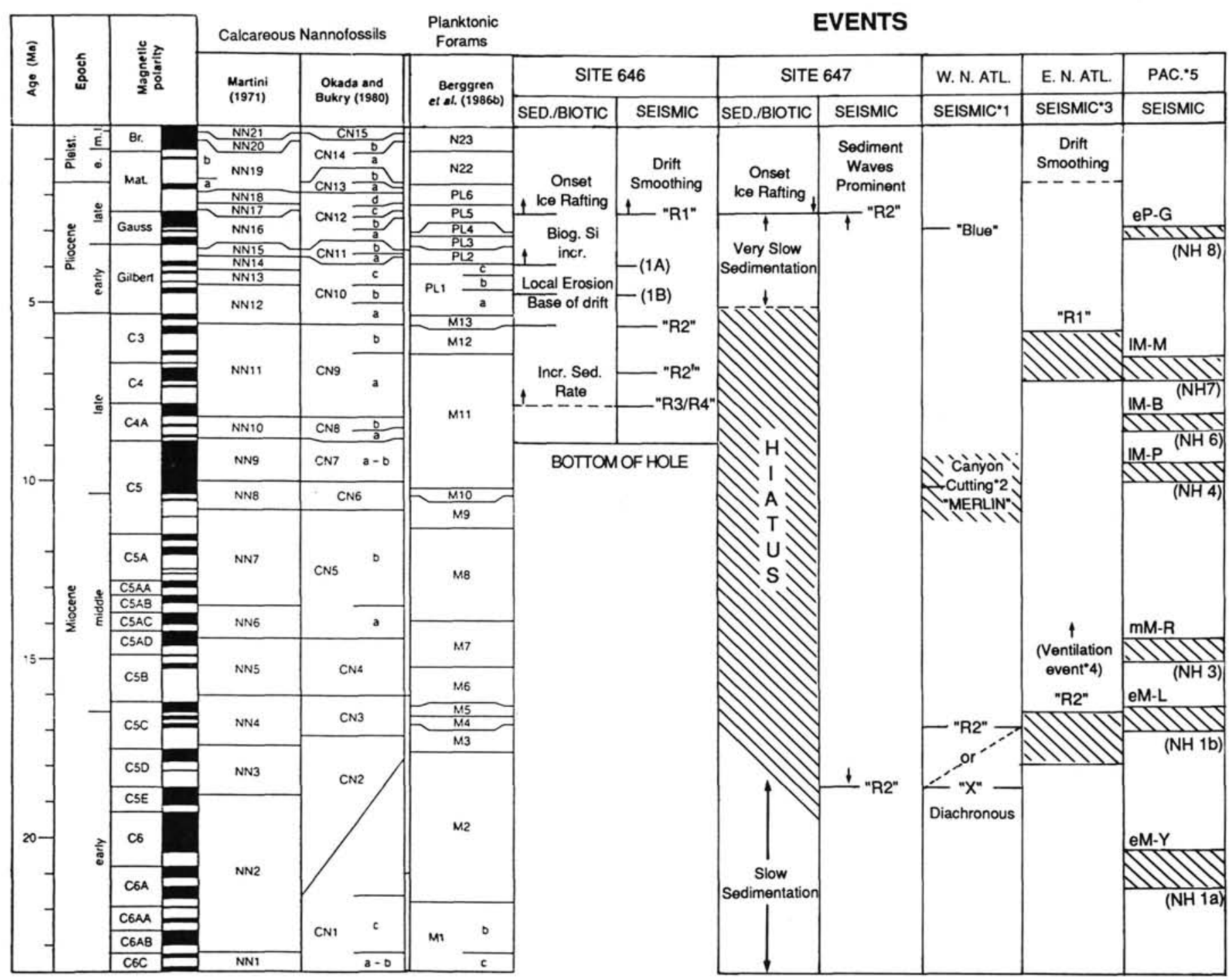

Figure 26. Chronostratigraphy (after Berggren et al., 1985), with timing of major seismic, lithologic, and paleoceanographic events for the North-Atlantic and Labrador Sea during the Neogene-Quaternary (see text).

curred at high latitudes and the Greenland-Scotland Ridge had subsided sufficiently (e.g., Vogt, 1972) to allow increasing spillover of deeper waters from the Norwegian-Greenland Sea.

Cooling in the Norwegian-Greenland Sea should have led initially to the production of colder, denser bottom water. The increased density contrast between intermediate water-masses in the North Atlantic and DSOW should have resulted in more vigorous circulation in the form of a western boundary undercurrent along the Greenland continental margin. Our drilling results at Site 646 thus demonstrated that this change to a "modern" circulation pattern occurred later in geologic history than previously thought (e.g., Tucholke and Mountain, 1986). The R2 reflector occurs within the upper part of seismic sequence 3 and lies below the Miocene/Pliocene boundary (4.85 Ma). No evidence of an erosional hiatus at R2, either at Site 646 or in the seismic lines occurs, but R2 may mark a change in bottom-current regime that presaged the major change near the early/late Pliocene boundary. Deposition at apparently high sedimentation rates $(96 \mathrm{~m} / \mathrm{m}$.y.) continued into the early Pliocene, but again little evidence of formation of a depositional ridge or even direct evidence of significant current-controlled deposition appears until the base of seismic sequence 2 (about $4.5 \mathrm{Ma}$ ). A number of features suggest that deposition was controlled by bottom currents, but that these were not particularly strong.

Chough et al. (1987) and Hesse et al. (1987) suggested that deposition of the sequence of turbidites in the NAMOC, which is as much as $0.5 \mathrm{~s}$ (perhaps $425 \mathrm{~m}$ ) thick, probably began about $2.5 \mathrm{Ma}$, coincident with the beginning of Northern Hemisphere glaciation. This inferred timing was based on the assertion that a major increase in the supply of terrigenous sediment to the region took place with the advent of glacial erosion of surrounding continents. Indeed, the correlation of our drilling results to a network of seismic lines demonstrates that the major part of the NAMOC deposits are $2.5 \mathrm{Ma}$ or younger. Figure 15 illustrates that reflector $\mathrm{R} 2$, an unconformity above upper Miocene strata overlain by terrigenous sediments dated at 2.4 to $2.5 \mathrm{Ma}$, passes beneath most, if not all, of the acoustically, well-laminated NAMOC deposits west of Site 647. The seismic records are not as clear as we would like, and we initially believed that part of the NAMOC deposits were older than $2.5 \mathrm{Ma}$ on the basis of our preliminary interpretations of the seismic records (Srivastava, Arthur, et al., 1987; Site 647 chapter).

For the upper $0.26 \mathrm{~s}$ above R2 under NAMOC, the extrapolated sedimentation rates are a maximum of $85 \mathrm{~m} / \mathrm{m} . \mathrm{y}$. This lat- 


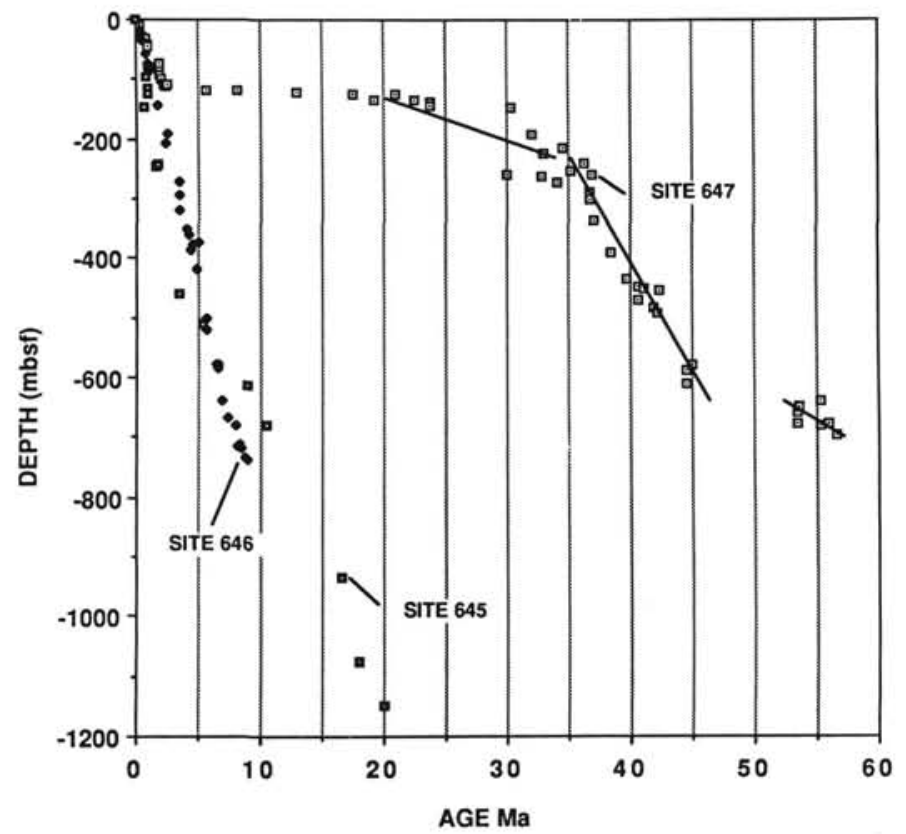

Figure 27. Sedimentation rates at Sites 645,646 , and 647, based on agedepth selections for important biostratigraphic and magnetostratigraphic events, after Baldauf et al. (this volume).

ter value is similar to that estimated for NAMOC deposits by Chough et al. (1987), who extrapolated sedimentation rates over the last glacial-interglacial cycle. Thus, it appears that important terrigenous sediment supply to the region occurred from at least $2.5 \mathrm{Ma}$ to the present through NAMOC, but that terrigenous influx could have begun earlier.

Drilling at DSDP Site 113 (Laughton, Berggren, et al., 1972) in the IMOC (Egloff and Johnson, 1975) north of Gloria Drift, indicates that high terrigenous sediment supply began as early as the latest Miocene to early Pliocene. At present, the IMOC is the major source of detritus to the lower NAMOC (Egloff and Johnson, 1975), which could suggest an earlier phase of terrigenous supply to NAMOC.

In seismic records over the southern part of Gloria Drift (Figs. $16,24)$, the highly reflective NAMOC deposits progressively onlap more transparent units below. An observable transition exists from the highly reflective western units to the less-reflective, nearly transparent eastern units. The acoustically transparent strata occur at somewhat shallower depths than the age-equivalent, highly reflective units. At least above reflector R3, these relationships suggest that Gloria Drift, on the margin of which Site 647 was drilled, consists primarily of fine-grained sediment that has been reworked, transported, and deposited by bottom currents. Well-developed sediment waves (hyperbolic echoes and reflectors) occur in the sequence above reflector R2, but discernment of such features is difficult below R2 in most seismic records. However, the diffractive returns above R4 in the main part of Gloria Drift (Fig. 24) represent sediment waves, or otherwise irregular deposits, resulting from bottom-current activity. These sediment waves and the shape of ridges on Gloria Drift (Egloff and Johnson, 1975) attest to the influence of deep currents in the construction of Gloria Drift.

Clearly, much of the Gloria Drift sequence has been formed above R2, which gives it a minimum age of late Miocene (5.6 $\mathrm{Ma}$ ) and a maximum age of $17.5 \mathrm{Ma}$. However, the records at ODP Site 647 and DSDP Site 112 suggest mainly upper Pliocene and Pleistocene sediment above R2; thicknesses of the upper recognizable drift unit of up to $0.26 \mathrm{~s}(300 \mathrm{~m})$ occur in the middle to southern part of Gloria Drift above R2 and average about $160 \mathrm{~m} \mathrm{(110} \mathrm{m}$ at Site $647 ; 135 \mathrm{~m}$ at Site 112 -both located in regions of thinner sediment).

At Eirik Ridge, deposition of seismic sequence 2 in the lateearly to late Pliocene (4.5-2.5 Ma) marked a distinct change in sedimentation in the region. The base of seismic sequence 2 lies unconformably above seismic sequence 3 over much of the area, except in the lee of the depositional ridges, such as Site 646, where sedimentation was apparently continuous across the contact between the two units. Buildup of the pronounced depositional ridges of seismic sequence 2 occurred mainly during the early to early-late Pliocene. Strata of seismic sequence 2 apparently climbed the slope at the top of seismic sequence 3 and progressively built a large ridge that began to prograde northward across the present position of Eirik Ridge. A segment of the BGR-1 line (Fig. 7) on the south flank of Eirik Ridge shows that much of seismic sequence 3 was eroded before or during deposition of a thin seismic sequence 2 there. A major flood of sediment to the region, probably from the source region of the IMOC (Laughton, Berggren, et al., 1972) also occurred during the time of seismic sequence 2 . Nearly $700 \mathrm{~m}$ of Pliocene turbidites, equivalent in age to our seismic sequence 2 at Site 646 , was deposited at rates of $35 \mathrm{~cm} / \mathrm{k} . \mathrm{y}$. $(350 \mathrm{~m} / \mathrm{m} . \mathrm{y}$.) at Site 113 . The high sediment supply, coupled with apparently increased current velocities, probably caused the episode of drift building.

Erosional modification of the drift sequence occurred in the late Pliocene. Large sediment waves formed at the top of the drift sequence, concomitant with the erosional episode. The erosion and formation of sediment waves might have resulted from a decrease in sediment supply and/or an increase in current velocities. Near the top of seismic sequence 2 , at about the beginning of erosional modification of the drift sequence (about $2.5 \mathrm{Ma}$ ), accumulation rates decrease at Site 646. This event post-dates the appearance of siliceous microfossils just below the early Pliocene/late Pliocene boundary (over the interval of 3.8 to $3.4 \mathrm{Ma}$ ). The event also post-dates a change in the benthic foraminiferal fauna, marked by disappearance of an agglutinated fauna and decline in abundance of calcareous benthic foraminifers (Kaminski et al., this volume). Calcareous plankton remains are somewhat better preserved above this interval. These events coincide with a significant change in deep-water properties, probably a change to a glacial bottom water derived from major cooling of Norwegian-Greenland Sea surface waters. An interesting correspondence, therefore, exists between surfaceand bottom-water changes at Site 646.

Seismic sequence 1 primarily represents deposition and smoothing of the seafloor under probably less vigorous deep circulation and waning sediment supply, even with the influx of ice-rafted, terrigenous material during latest Pliocene and Pleistocene time (2.5-0 Ma). Sediments of seismic sequence 1 cover the entire region but vary in thickness. These sediments are thickest on the lee side of the depositional ridge and do not simply drape previous topography.

Thus, major sediment drift formation in the Labrador Sea began about $4.5 \mathrm{Ma}$, on Eirik Ridge, with a major event at about 3.2 to $3.2 \mathrm{Ma}$, marked by a pronounced change in benthic foraminiferal faunas (Kaminski et al., this volume) and a surface-water biotic change as well, and at least $2.5 \mathrm{Ma}$ or older on Gloria Drift. Both events were accompanied by an increase in the regional sedimentation rate (Fig. 27), probably because of increased glacial erosion, lowering of sea level, feeding of sediment through major mid-ocean canyon systems (NAMOC and IMOC; Hesse et al., 1987), and velocity of bottom currents. Our drilling results help to constrain the ages of the major sediment supply to IMOC and NAMOC as having occurred in the late Pliocene. In the western North Atlantic, reflector "Blue" (Mountain and Tucholke, 1985) is about of this age and is interpreted as indicating increased sediment supply to drifts during 
the late Pliocene. Again, this may have been a global-scale, deep-water mass event (Mayer et al., 1986), corresponding to reflector eP-G in the Pacific. However, no major event of that age appears on either the Gardar or Feni drifts in the eastern North Atlantic (e.g., Kidd and Hill, 1986b).

Major drift sedimentation in the Labrador Sea may have been dependent on sediment supply, as well as on the strength of bottom currents. Although major deep-circulation events occurred from the mid-Miocene on, drifts were not formed until the mid-Pliocene in the Labrador Sea. Major climatic (surfacewater) events at high latitude generally produced sympathetic deep-circulation events, marked by seismic horizons and benthic foraminiferal changes. The question remains as to whether Baffin Bay was a source of deep-water masses in the MiocenePliocene, but there is certainly evidence of vigorous deep circulation from mid-Miocene on in that basin.

\section{CONCLUSIONS}

The results of drilling and interpretation of seismic-reflection records at and across Leg 105 Sites 645, 646, and 647 constrain the history of deep-water circulation and sedimentation response as the result of late Cenozoic climate deterioration at high latitudes. Sites 646 and 647 were drilled on the flanks of two major sediment drift deposits in the Labrador Sea. Sediment at Site 646 was deposited at high rates, providing a highresolution record of the last 8.6 Ma of deposition on Eirik Ridge. At Site 647 on Gloria Drift, sedimentation was variable and discontinuous, but a complete upper-lower Eocene through lower Oligocene sequence was recovered. The upper Oligocene to Holocene sequence was interrupted by several major hiatuses. Although age control at Site 645 (in Baffin Bay) was poor, because of the environmentally restricted biotas there, this drill site provides a more or less continuous lower Miocene to Holocene sequence.

The drift sequence at Site 646 was constructed largely after the mid-early Pliocene (ca. 4.5 Ma). Evidence exists for variable bottom-current activity prior to that, with events at about 7.5 $\mathrm{Ma}$ (a change in water-mass characteristics and increasing velocities) and $5.6 \mathrm{Ma}$ (an increase in current velocity preceding the major 4.5 Ma event; R2 regional reflector). The 7.5-Ma event produced a major regional reflector (R3/R4), which was originally thought to be Eocene/Oligocene in age. A major change in water mass also occurs at the onset of ice rafting at about 2.5 Ma. At Site 646 each of the major inferred changes in bottomwater circulation is accompanied by a pronounced change in benthic foraminiferal faunas. A probable late-middle Miocene erosional event, the age of which is not constrained by drilling results, is seen in seismic records on the south flank of Eirik Ridge and along the West Greenland margin and precedes drift construction. Sediment supply from the IMOC increased concurrently with the advent of drift buildup in the early Pliocene. Sediment supply, as well as current strength, is probably important in drift construction, as opposed to widespread erosion.

Gloria Drift was also built largely after the late Miocene. The major increase in sediment supply occurred in the early Pliocene, following a major hiatus and condensed sequence (17.5 to $2.5 \mathrm{Ma}$ ), and most seismic records from the drift exhibit sediment waves above this horizon. The increased sediment supply is the result of hemipelagic deposition from encroaching deposits of NAMOC, as well as of supply of ice-rafted detritus in the late Pliocene (2.5 Ma). A major regional reflector (R3) corresponds to a change from calcareous to opal-rich hemipelagic strata (above) in the lower Oligocene. Previous scientists suggested that R3 reflected increased bottom-water activity and erosion near the Eocene/Oligocene boundary. There is some mineralogical and textural evidence to support a latest Eocene to earliest Oligocene change in bottom-current characteristics in the region and benthic foraminiferal evidence that suggests the appearance of younger, more oxygenated bottom water.

In Baffin Bay, evidence also exists for bottom-water activity, both from textural studies of cores and from apparent drift features exhibited in multichannel lines along the western margin. Contour currents have been active since at least the late middle Miocene, with episodes of decreasing intensity that apparently occurred in the late Miocene and Quaternary. Formation of dense, deep water may have occurred in the late Neogene in Baffin Bay in conjunction with climatic deterioration, but although it is possible that this dense water added to the flux of deep water formed in the Norwegian-Greenland Sea, Baffin Bay probably was not an important source of deep-water masses to the Labrador Sea after the late Pliocene.

Not surprisingly, many of the Labrador Sea deep-circulation events correspond to major North Atlantic events and to important global climatic and paleoceanographic events. However, the major drift-building episode may have occurred later in the Labrador Sea than it did in either the eastern North Atlantic or the western North Atlantic. The western North Atlantic "Merlin" event (ca. 10-12 Ma) that marks the base of stable drift development there (Tucholke and Mountain, 1986) may be equivalent to a late Miocene reflector in the Rockall Trough region. Reflector "Blue" in the western North Atlantic of mid-Pliocene age is thought to represent a change in style of drift sedimentation related to increased sediment supply (e.g., Mountain and Tucholke, 1985); this event is probably equivalent to our reflector R2 on both drifts in the Labrador Sea.

The primary criteria for timing of bottom-current activity and construction of sediment drifts are the reflection characteristics of the seismic sequences (e.g., McCave and Tucholke, 1986; Stow and Holbrook, 1984). In contrast, sediment from Gloria and Eirik drifts in the Labrador Sea recovered in our drill sites is primarily bioturbated to homogeneous (see also Chough and Hesse, 1985), hemipelagic mud belying the strength of deep currents that must have sculpted the drift deposits. However, ODP Sites 646 and 647 were drilled in regions of presumed more continuous sedimentation to provide ages for major seismic reflectors, thus avoiding the areas having seismic characteristics that suggest more intense bottom-current activity. Future drilling should target one drift and attempt to recover sediment sequences that exhibit a range of seismic characteristics to better understand the history of deep-water evolution and complexities of drift formation. Eirik Drift presents a good opportunity for such research.

\section{ACKNOWLEDGMENTS}

We heartily thank the captain and crew of the JOIDES Resolution, the Sedco drilling crew, and the ODP technicians for their diligent efforts to sail a straight course, to pull core on board, and to punch logging tools downhole. We particularly acknowledge the perseverance and knowhow of Lamar Hayes, ODP Operations Superintendent, without whom we would not have been able to core successfully in the sea conditions that prevailed in the Labrador Sea during Leg 105. We also are indebted to Petro Canada for releasing multichannel seismic lines from Baffin Bay and to the crew of the Hudson for collecting site survey data over Sites 646 and 647. Carl Brenner kindly supplied copies of Vema lines from the ODP data bank at Lamont-Doherty Geological Observatory. Sheila Haggerty Rieg and Rhonda Kenny helped to prepare this manuscript, and we thank them for their patience and hard work. Most of all, we appreciate the efforts of Brad Clement and the rest of the shipboard party who aided us in our efforts by furnishing data and discussion relevant to this study.

\section{REFERENCES}

Aksu, A. E., and Mudie, P. J., 1985. Magnetostratigraphy and palynology demonstrate at least four million years of Arctic Ocean sedimentation. Nature, 818:280-283.

Berggren, W. A., 1972. Cenozoic biostratigraphy and paleobiogeography of the North Atlantic. In Laughton, A. S., Bergren, W. A., et 
al., Init. Repts. DSDP, 12: Washington (U.S. Govt. Printing Offce), 965-1002.

Berggren, W. A., Kent, D. V., and Flynn J. J., 1985. Paleogene geochronology and chronostratigraphy. In Snelling, N. J. (Ed.), Geochronology and the Geologic Time Scale. Geol. Soc. (London) Mem., 10: 141-195.

Berggren, W. A., Kent, D. V., and Van Couvering, J. A. 1986. Neogene geochronology and chronostratigraphy. In Snelling, N. J. (Ed.), Geochronology and the Geologic Time Scale. Geol. Soc. (London) Mem., 10:211-250.

Berggren, W. A., and Schnitker, D., 1983. Cenozoic marine environments in the North Atlantic and Norwegian-Greenland Sea. In Bott, M.H.P., Saxov, S., Talwani, M., Thiede, J. (Eds.), Structure and Development of the Greenland-Scotland Ridge-New Methods and Concepts. NATO Conf. Ser. IV, 8:495-548.

Chough, S. K., and Hesse, R., 1985. Contourites from Eirik Ridge, South of Greenland. Sediment. Geol., 41:185-199.

Chough, S. K., Hesse, R., and Muller, J., 1987. The Northwest Atlantic Mid-Ocean Channel of the Labrador Sea: IV, petrography and provenance of the sediments. Can. J. Earth Sci., 12:2111-2133.

Clark, D. L., 1982. Origin, nature, and world climate effect of Arctic Ocean ice-cover. Nature, 300:321-325.

Egloff, J., and Johnson, G. L., 1975. Morphology and structure of the southern Labrador Sea. Can. J. Earth Sci., 12:2111-2133.

Eldholm, O., Thiede, J., Taylor, E., et al., 1987. Proc. ODP, Init. Repts., 104: College Station, TX (Ocean Drilling Program).

Garner, D. M., 1972. Flow through Charlie-Gibbs Fracture Zone, MidAtlantic Ridge. Can. J. Earth Sci., 9:116-121.

Gassman, F., 1951. Elastic Waves through a packing of spheres. Geophysics, 26:673-685.

Gradstein, F. M., and Srivastava, S. P., 1980. Aspects of Cenozoic stratigraphy and paleoceanography of the Labrador Sea and Baffin Bay. Palaeogeogr., Paleoclimatol., Palaeoecol., 30:261-295.

Harvey, J. G., 1980. Deep and bottom water in the Charlie-Gibbs Fracture Zone. J. Mar. Res., 38:172-173.

Hesse, R., Chough, S. K., and Rakovsky, A., 1987. The northwest Atlantic Mid-Ocean Channel of the Labrador Sea: V, sedimentology of a giant deep-sea channel. Can. J. Earth Sci., 24:1595-1624.

Hinz, K., Schlüter, H.-U., Grant, A. C., Srivastava, S. P., Umpleby, D., and Woodside, J., 1979. Geophysical transects of the Labrador Sea: Labrador to southwest Greenland. Tectonophysics, 59:151-183.

Hooper, P.W.P., and Weaver, P.P.E., 1986. Paleoceanographic significance of late Miocene to early Pliocene planktonic foraminifers at Deep Sea Drilling Project Site 609. In Ruddiman, W. F., Kidd, R. B., Thomas, E., et al., Init. Repts. DSDP, 94: Washington (U.S. Govt. Printing Offce), 925-934.

Johnson, G. L., and Schneider, E. D., 1969. Depositional ridges in the North Atlantic. Earth Planet. Sci. Lett., 6:416-422.

Jones, E. J., Ewing, M., Ewing, J. I., and Eittreim, S. L., 1970. Influences of Norwegian Sea overflow on sedimentation in the northern North Atlantic and the Labrador Sea. J. Geophys. Res., 75:16551680.

Keller, G., and Barron, J. A., 1983. Paleoceanographic implications of Miocene deep-sea hiatuses. Geol. Soc. Am. Bull., 94:590-613.

Kidd, R. B., and Hill, P. R., 1986a. Sedimentation on mid-ocean sediment drifts. In Summerhayes, C. P., and Shackleton, N. J. (Eds.), North Atlantic Paleoceanography. Geol. Soc. Am. Spec. Publ., 21: 87-102.

1986b. Sedimentation of Fenl and Gardar Sediment drifts. In Ruddiman, W. F., Kidd, R. B., Thomas, E., et al., Init. Repts. DSDP, 94: Washington (U.S. Govt. Printing Offce), 1217-1244.

Laughton, A. S., Berggren, W. A., et al., 1972. Init. Repts. DSDP, 12: Washington (U.S. Govt. Printing Office), 1155-1179.

Masson, D. G., and Kidd, R. B., 1986. Revised seismic stratigraphy of the southern Rockall Trough. In Ruddiman, W. F., Kidd, R. B., Thomas, E., et al., Init. Repts. DSDP, 94: Washington (U.S. Govt. Printing Office), 1117-1126.
Mayer, L. A., Shipley, T. H., and Winterer, E. L., 1986. Equatorial Pacific seismic reflectors as indicators of global oceanographic events. Science, 233:761-764.

McCave, I. N., and Tucholke, B. E., 1986. Deep current-controlled sedimentation in the western North Atlantic. In Vogt, P. R., and Tucholke, B. E. (Eds.), The Geology of North America, Vol. M, The Western North Atlantic Region: (city) (publisher), 451-468.

Miller, K. G., and Tucholke, B. E., 1983. Development of Cenozoic abyssal circulation south of the Greenland-Scotland Ridge. In Bott, M.H.P., Saxov, S., Talwani, M., Thiede, J. (Eds.), Structure and Development of the Greenland-Scotland Ridge: New York (Plenum), 549-589.

Miller, K. G., Melillo, A. J., Mountain, G. S., Farre, J. A., and Poag, C. W., 1987. Middle to late Miocene canyon cutting on the New Jersey continental slope: biostratigraphic and seismic stratigraphic evidence. Geology, 15:509-512.

Miller, K. G., Fairbanks, R. G., and Mountain, G. S., 1989. Tertiary oxygen isotope synthesis, sea level history, and continental margin erosion. Paleoceanography, 2(1):1-19.

Moore, T. C., Jr., van Andel, T. H., Sancetta, C., and Pisias, N., 1978. Cenozoic hiatuses in pelagic sediments. Micropaleontology, 24:113138.

Mountain, G. S., and Tucholke, B. E., 1985. Mesozoic and Cenozoic geology of the U.S. Atlantic continental slope and rise. In Poag, C. W. (Ed.), Geologic Evolution of the U.S. Atlantic Margin: New York (Van Nostrand Reinhold), 293-341.

Murray, J. W., 1984. Paleogene and Neogene benthic foraminifers from Rockall Plateau. In Roberts, D. G., Schnitker, D., et al., Init. Repts. $D S D P, 81$ : Washington (U.S. Govt. Printing Office), 503-534.

Roberts, D. G., Montadert, L., and Searle, R. C., 1979. The western Rockall Plateau: stratigraphy and structural evolution. In Montadert, L., Roberts, D. G., et al., Init. Repts. DSDP, 48: Washington (U.S. Govt. Printing Offce), 1066-1088.

Roberts, D. G., Schnitker, D., et al., 1984. Init. Repts. DSDP, 81: Washington (U.S. Govt. Printing Offce).

Schnitker, D., 1986. Northeast Atlantic Neogene benthic foraminiferal faunas-tracers of deep-water paleoceanography. In Summerhayes, C. P., and Shackleton, N. J. (Eds.), North Atlantic Paleoceanography. Geol. Soc. (London) Spec. Publ., 21:191-303.

Shackleton, N. J., Backman, J., Zimmermann, H. B., Kent, B. V., Hall, M. A., Roberts, D. G., and Schnitker, D., 1984. Oxygen isotope calibration of the onset of ice rafting in DSDP Site 552A: history of glaciation in the North Atlantic region. Nature, 307:620623.

Shor, A., Lonsdale, P., Hollister, C. D., and Spencer, D., 1980. CharlieGibbs Fracture Zone: bottom-water transport and its geological effects. Deep-Sea Res., 27:325-342.

Srivastava, S. P., Arthur, M. A., et al., 1987. Proc. ODP, Init. Repts., 104: College Station, TX (Ocean Drilling Program).

Stow, D.A.V., and Holbrook, J. A., 1984. North Atlantic contourites: an overview. In Stow, D.A.V., and Piper, D.J.W. (Eds.), Fine-Grained Sediments: Deep-Water Processes and Facies. Geol. Soc. Am. Spec. Publ., 15:245-256.

Tucholke, B. E., and Mountain, G. S., 1986. Tertiary paleoceanography of the western North Atlantic Ocean. In Vogt, P. R., and Tucholke, B. S. (Eds.), The Geology of North America, Vol. M, The Western North Atlantic Region: Alexandria, VA (Geol. Soc. Am.), 631-650.

Vogt, P. R., 1972. The Faeroe-Iceland-Greenland seismic ridge and the western boundary undercurrent. Nature, 239:79-86.

Worthington, L. V., and Volkman, G. H., 1965. The volume transport of the Norwegian Sea overflow in the North Atlantic. Deep-Sea Res., 12: 667-676.

Date of initial receipt: 28 May 1988

Date of acceptance: 23 May 1989

Ms 105B-118 